\title{
Essay
}

\section{A Contract Theory Approach to Business Bankruptcy}

\author{
Alan Schwartz ${ }^{\dagger}$
}

Business bankruptcy systems attempt to solve a coordination problem for the creditors of insolvent firms. Some insolvent firms cannot earn revenues sufficient to cover nonfinancing costs. The assets of these firms can be put to better uses elsewhere, so the assets should be sold off.' Other insolvent firms earn revenues that exceed production costs but that are too low to service the firm's debt. These firms should be continued as going concerns under less leveraged capital structures. As is well known, ${ }^{2}$ an individual creditor is not interested in this distinction: The creditor would rather maximize returns by attaching assets sufficient to pay its claim in full. If every creditor attempts to attach assets, the firm will be liquidated piecemeal, whether it is efficient to continue the firm or not.

Creditors as a group would prefer to coordinate their collection actions so that the debtor firm is liquidated piecemeal only when that would raise more money for creditors than continuing the firm-"reorganizing" it—would raise. Creditors are widely believed to have high coalition costs, however, and there is credible evidence for this view: Private workouts after insolvency often fail. ${ }^{3}$ Western bankruptcy systems commonly respond to this creditors' problem by enacting coordination mechanisms. These mechanisms prevent some or all creditors from collecting debts individually and establish

i Sterling Professor of Law, Yale Law School. This Essay benefited from comments by Bamy Adler. Frank Buckley, Henry Hansmann, Ronald Mann, Gideon Parchomovsky, Robert Rasmussen, Roberta Romano, Eric Talley, and participants at the 1997 European Association of Law and Economics Meeting and at workshops at the University of Southem Califomia. Yale. and Virginia Law Schools.

1. Selling off the assets of insolvent firms commonly is denoted "picoemeal liquidation." Barry $E$. Adler, A Theory of Corporate Insolvency, 72 N.Y.U. L. REV. 343. 360 n.62 (1997).

2. See, e.g., ThOMAS H. JACKSON, THE LOGIC AND Limits OF BANKRUPTCY LAW 7-19 (1986).

3. See Alan Schwartz, Bankruptcy Workouts and Debr Contracts, 36 J.L. \& EcoN. S9S, 595 n.I (1993) (summarizing studies). 
procedures to make the value-maximizing choice between liquidation and reorganization. The value of the insolvent firm is then distributed to creditors who participate in the bankruptcy procedure according to a priority scheme.

Western countries require the debtor and many (sometimes all) creditors to participate in the state-supplied bankruptcy system and restrict the ability of parties to alter certain outcomes that the state system directs. ${ }^{4}$ To appreciate these peculiar bankruptcy features, recall that the typical commercial dispute is resolved by a court but parties can contract for a different dispute resolution procedure, such as arbitration. The typical body of commercial law also is a set of defaults; the rules govern unless particular parties choose different rules in their contract. ${ }^{5}$ In contrast, parties cannot contract in lending agreements to use a bankruptcy system other than the one the state supplies. ${ }^{6}$ Also, parties cannot modify many of the rules that constitute the system. For example, the Uniform Commercial Code (U.C.C.) permits a party to cancel a deal if its contract partner becomes insolvent, ${ }^{7}$ and parties have commonly made the Code's authorization explicit by contracting for a right to exit. ${ }^{8}$ Today, bankruptcy law permits the insolvent party (or its bankruptcy trustee) to keep a sales contract in force despite state law or private agreement. ${ }^{9}$

That bankruptcy systems solve a coordination problem rather than regulate the substance of transactions accounts for some of the distinctions between bankruptcy and commercial law generally. For example, if contracting were otherwise unregulated, a contractual term authorizing creditors to collect promptly and in full upon default should not be enforced because enforcement of such terms would result in piecemeal liquidations. Structural rules of the game must be mandatory or the game cannot be played at all. Bankruptcy systems, however, contain more mandatory rules than a structural account can explain.

This Essay makes three claims regarding the restrictive features of modern bankruptcy systems. The first claim follows from the recognition that the optimality of a bankruptcy system is state-dependent. Reorganizing an insolvent firm sometimes would maximize revenue, while liquidating the same firm would be best under other values of the relevant economic parameters. The United States recognizes the state-dependent optimality of bankruptcy

4. These restrictions are discussed in I REPORT OF THE NATIONAL BANKRUPTCY REVIEW COMMISSION 459-87 (1997) [hereinafter NATIONAL BANKRUPTCY REVIEW COMMISSION]. The Commission was appointed by Congress to recommend possible bankruptcy law reforms. See id. at 47-53.

5. Section 1-102(3) of the Uniform Commercial Code (U.C.C.) authorizes parties to vary "the effect of provisions of this Act" except for the "obligations of good faith, reasonableness, diligence and care." U.C.C. § 1-102(3) (1989).

6. See, e.g., In re Madison, 184 B.R. 686, 690-91 (Bankr. E.D. Pa. 1995); In re Weitzen, 3 F. Supp. 698, 698 (S.D.N.Y. 1933) (citing Federal Nat'l Bank v. Koppel, 148 N.E. 379 (Mass. 1925)).

7. See U.C.C. \& 2-609.

8. These clauses were outlawed by the 1978 Bankruptcy Code. See 11 U.S.C. \& 365(c) (1994); see also S. REP. No. 95-989, at 59 (1978), reprinted in 1978 U.S.C.C.A.N. 5787, 5845.

9. See 11 U.S.C. $\$ 365(\mathrm{e})$. 
systems by authorizing a court to decide ultimately whether an insolvent firm should be liquidated or reorganized. ${ }^{10}$ This Essay shows that parties could improve on this solution with contracts that induce the use of the system that is optimal in their particular circumstances. These contracts, therefore, should be legal.

The Essay's second claim is that the only mandatory rules in a bankruptcy system should be structural. The current U.S. Bankruptcy Code contains mandatory structural rules as well as mandatory rules whose goal is to augment the value of the bankrupt estate. The rule barring the solvent party from canceling a contract with the insolvent party is such a rule: It requires the solvent party to perform at a possible loss if the deal is profitable to the estate." There is, however, no good distributional reason to benefit one set of business creditors - the "estate"-at the expense of another set-the solvent party. Nonstructural mandatory bankruptcy rules are justifiable only if they increase ex post efficiency. The cancellation rule, therefore, should require the solvent party to perform only when the estate's gain from performance would exceed the solvent party's loss.

It does not follow, however, that bankruptcy law should attempt to increase ex post efficiency with mandatory rules. The Coase Theorem teaches that, when certain conditions hold, the initial location of a property right, as set by mandatory rules, is irrelevant to efficiency. Bankruptcy systems create mechanisms to facilitate Coasean bargaining. These systems often appoint a state official to represent the bankrupt estate, ${ }^{12}$ and the official can bargain with creditors, such as the solvent party in the example here. Nonstructural mandatory bankruptcy rules are thus needed only when the conditions for Coasean bargaining do not obtain. This Essay shows that bargaining succeeds with respect to money: Renegotiation after insolvency will shift tangible wealth to the estate when it is efficient to do so but not otherwise, whether or not a mandatory rule is present. Because bankruptcy systems should function to maximize the monetary value of the estate, ${ }^{13}$ these systems need not contain mandatory redistributional rules. Therefore, the only mandatory rules in a bankruptcy system should be structural.

The two claims just summarized implicitly assume that bankruptcy systems exist only to increase efficiency by solving the creditors' coordination problem. Many American commentators argue that bankruptcy systems also should protect persons or entities who do not have current claims against the insolvent

10. See 11 U.S.C. $\$ \S 105(a), 305(a), 1129(a)$.

11. See id. $\$ 365$.

12. Sections 701-703 of the Bankruptcy Code provide for the appointment of a trustec to represent the bankrupt estate, and $\S 704$ sets out the trustec's duties. See id. $\$ \S 701-704$.

13. This Essay uses the phrases "solve the creditors' coordination problern" and "maximize the monetary value of the estate" interchangeably because the point of solving the problem is to maximize value. 
firm. In the literature, protected classes include workers with an interest in continued employment and local communities that benefit from the firm's continued presence. ${ }^{14}$ Perhaps more of the American system's mandatory character could be justified if the system were meant to protect nonparties, but this Essay's third claim is that the better arguments hold that bankruptcy systems should solve only the creditors' coordination problem. ${ }^{15}$

The importance of this Essay's topic is evidenced by recent commercial practice and scholarly comment. Business parties have become increasingly dissatisfied with the U.S. system and are attempting to avoid it despite apparent legal prohibitions. The National Bankruptcy Review Commission observed:

While it was long ago assumed that specific rights, effects, or obligations provided by the Bankruptcy Code could not be waived in advance even in the absence of an express nonwaivability Code provision, case law and business practice have begun to call this longheld assumption in question. With increasing regularity, loan documents and workout agreements contain clauses waiving the automatic stay [of creditor collection rights] if the borrower files for bankruptcy. ${ }^{16}$

The Commission added: "Other typical clauses provide that filing a [bankruptcy] petition will constitute 'bad faith' if intended to forestall foreclosure, or that the debtor agrees to admit the existence of facts that will support a case dismissal order." ${ }^{17}$ The Commission responded to these efforts to avoid bankruptcy by recommending that the Bankruptcy Code be amended to make explicit that "a clause in a contract or lease ... does not waive, terminate, restrict, condition, or otherwise modify any rights or defenses provided by Title 11 " of the Code. ${ }^{18}$

Scholars, meanwhile, have made three recent contributions to the debate about the mandatory character of bankruptcy systems. These contributions are consistent with this Essay's claim that parties should be free to choose preferred bankruptcy systems in their lending agreements. First, some scholars argue that requiring parties to use the state-supplied system is not a serious

14. The National Bankruptcy Review Commission, reflecting this view of banknuptcy, introduced its chapter on business bankruptcies by approvingly describing U.S. reorganization law: "Principally through Chapter 11, business bankruptcy creates the opportunity to restructure failing businesses, to preserve jobs, to prevent the spread of economic failure to smaller suppliers and other dependent businesses, and to permit communities to retain their tax base." I NATIONAL BANKRUPTCY REVIEW COMMISSION, supra note 4, at 303. Articles urging this position are discussed infra notes 32-41 and accompanying text.

15. Tort and environmental victims of the firm's activities do not bargain with the firm ex ante, but do have current bankruptcy claims against it. These claims should be protected in bankruptcy, but just how is beyond this Essay's scope.

16. 1 NATIONAL BANKRUPTCY REVIEW COMMISSION, supra note 4, at 479.

17. Id. at 479 n.1162.

18. Id. at 478 . The Commission's reasons are discussed infra text accompanying notes 75-78. 
constraint. Firms may avoid any such system by selecting "bankruptcy-proof" capital structures. ${ }^{19}$ For example, firms that eschew debt cannot go bankrupt. Firms, however, choose capital structures to solve agency problems between the firm's managers or owners and outside investors. ${ }^{20}$ Firms thus face the difficult problem of choosing between a suboptimal capital structure that would avoid bankruptcy or reduce bankruptcy costs and an otherwise optimal capital structure that will compel the firm, if insolvent, to use a suboptimal bankruptcy system. This choice could be avoided if firms were free to contract directly for a preferred bankruptcy procedure.

Second, some scholars have argued that a firm should be permitted to choose its preferred bankruptcy system in its corporate charter. Creditors of the firm would be bound by the firm's charter choice. ${ }^{21}$ This solution may founder over the problem that because the optimality of a bankruptcy system is state-dependent, it also can be time-dependent. Put more simply, time may render a company's charter solution outmoded, and corporate charters are inconvenient to amend. Some firms would likely prefer the relative flexibility of using lending agreements to induce the choice of optimal bankruptcy systems.

Finally, some courts and scholars argue that firms should be permitted to waive in workout agreements certain sections of the Bankruptcy Code, such as the automatic stay. ${ }^{22} \mathrm{~A}$ workout agreement is made between the firm and some or all of its creditors after the firm has experienced financial distress. This Essay does not discuss workout agreements, but it does show that efficiency would sometimes be enhanced were firms also free to contract about bankruptcy in ex ante lending agreements.

In light of the recent extensive debate in law reviews about the appropriate functions of a bankruptcy system, ${ }^{23}$ and the discussion of contracting issues

19. See, e.g., Barry E. Adler, Financial and Political Theories of American Corporale Banksupicy. 45 STAN. L. REV. 311, 322 (1993); Douglas G. Baird, The Hidden Virtues of Chapler 11 (1997) (unpublished manuscript, on file with the Yale Law Journal).

20. See, e.g., PAUl Milgrom \& John Roberts, Economics, Organization and MANAgement 448. 535 (1992); OLIVER E. WILLIAMSON, THE MEChaNISMS OF GOVERNANCE 171 -94 (1996).

21. See, e.g., Robert A. Haugen \& Lemma W. Senbel, Bankruptcy and Agency Costs: Their Significance to the Theory of Optimal Capital Structure, 23 J. FIN. \& QUANTITATIVE ANALYSIS 27. 29-31 (1988); Robert K. Rasmussen, Debior's Choice: A Menu Approach to Corporate Bantrupicy. 71 TEx. L. REV. 51, 53-54 (1992). Randy Picker has angued that a normatively desirable banknuptcy law should reflect the contracting choices that private parties would make, were transaction costs low, but he does not discuss the possibility of a firm's actually choosing a procedure in a corporate charter or contrat. See Randal C. Picker, Voluntary Petitions and the Creditors' Bargain, 61 U. CIN. L. REV. 519, 526 (1992). Steven Schwarez recently approached the freedom-of-contract question by asking generally when parties should be permitted to contract out of statutory schemes, concluding that there should be considerably more freedom to contract about bankruptcy issues than now exists. See Steven L. Schwarcz. Freedom To Contract About Bankruptcy (Jan. 21, 1998) (unpublished manuscript, on file with the Yale Law Journal).

22. Cases and articles to this effect, as well as competing authorities, are cited in I NAmoNAl BANKRUPTCY REVIEW COMMISSION, supro note 4, at 478-87.

23. Good reviews are Douglas G. Baird, Banktuptcy's Uncontested Arioms. 108 YALE LJ. (forthcoming Oct. 1998); Christopher W. Frost, Bankruptcy Redistriburive Policies and the Limits of the Judicial Process, 74 N.C. L. REv. 75 (1995); and Donald R. Korobkin. The Role of Normarive Theory in 
just summarized, this Essay covers some ground that will be familiar to those in the field. The additions are an explanation of the economic effects of preventing parties from contracting for a preferred bankruptcy system in the lending agreements (and a demonstration that parties could solve their coordination problem at the credit extension stage and so would write efficient "bankruptcy contracts" if they were free to do so); an explanation of how mandatory bankruptcy rules work and an argument that bankruptcy systems should have few of these rules; and a somewhat different set of reasons to support the view that bankruptcy law should solve only the creditors' coordination problem. The analyses that support these results use modern contract theory, thus explaining the Essay's title.

Part I argues that bankruptcy should protect only those holding current claims against the insolvent firm. Part II analyzes the problem of contracting for preferred bankruptcy systems, and Part III discusses mandatory bankruptcy rules. There is a methodological and a substantive lesson in this analysis. A recent scholarly trend treats commercial and business law issues as contracting problems. The view that a corporation is a nexus of contracts between the various inputs to production is perhaps the most famous example. ${ }^{24}$ Contracting approaches have begun to influence bankruptcy law as well. The methodological lesson is that contractual influence should increase. The substantive lesson is that bankruptcy systems should contain fewer barriers to free contracting than they now do.

\section{THE GoALS OF A BANKRUPTCY SySTEM}

\section{A. The Current Debate}

\section{The Efficiency Goal}

Economic commentators argue that a bankruptcy system should maximize the ex post value of the insolvent firm and distribute this value to current claimants according to the absolute priority rule. ${ }^{25}$ To follow absolute priority

Bankruptcy Debates, 82 IOWA L. REV. 75 (1996).

24. A thorough summary of the economic literature developing this view is contained in Jean-Jacques Laffont \& David Martimort, The Firm as a Multi Coniract Organization, 6 J. ECON. \& MGMT. STRATEOY 201 (1997). A more accessible treatment is HENRY HANSMANN, THE OWNERSHIP OF ENTERPRISE 18-20 (1996).

25. The leading proponents of this view are Douglas Baird and Thomas Jackson. Their cascbook strongly argues that bankruptcy courts should respect state law entitlements, an argument that implics respecting the entitlements that constitute a firm's priority structure. See DOUGLAS G. BAIRD \& THOMAS H. JACKSON, CASES, PROBLEMS AND MATERIALS ON BANKRUPTCY (2d ed. 1990); see also, e.g., Douglas G. Baird, Revisiting Auctions in Chapter 11, 36 J.L. \& ECON. 633, 636 (1993); Douglas G. Baird \& Thomas H. Jackson, Corporate Reorganizations and the Treatment of Diverse Ownership Interests: A Commentary on Adequate Protection of Secured Creditors in Bankruptcy, 51 U. CH1. L. REV. 97 (1984). Jackson's views heavily influenced the new German Insolvency Act. See Klaus Kamlah. The New German Insolvency Act: Insolvenzordnung, 70 AM. BANKR. L.J. 417, 421 (1996). 
is to pay debts in the order stipulated by the firm's contracts with investors. ${ }^{26}$ Thus, under the rule, lenders are paid before shareholders and lenders with mortgages are paid before lenders without mortgages. This economic view is helpfully clarified by explaining the relevance of bankruptcy law to the firm's financing decisions. The efficiency goal holds that the object of business law, broadly speaking, is to maximize social wealth. A bankruptcy law can help to achieve this goal by reducing the costs of debt capital. Reducing such costs permits firms to fund more good projects and creates better incentives for firms to maximize value.

An example may help to explain these points. Assume that a firm has a project to pursue but has no money, and that it decides to raise debt capital. The project costs $\$ I$ to do. If the project succeeds, the firm will earn more than the project's cost, but if the project fails, the firm will earn less (i.e., the firm will be insolvent). The firm can induce creditors to lend the cost $I$ by promising to repay the sum $F$ if the project succeeds. If the project fails, the creditors are entitled to take the firm (which is worth less than the sum lent). Denote the firm's value if the project fails as $y$. As will appear, $y$ is partly a function of the bankruptcy system that is in place. The costs of this system are denoted $c$.

In a competitive credit market, creditors will expect to break even on loans (including a return on a creditor's investment). This "break even constraint" will be satisfied in the example here if the firm promises to repay a sum whose expected value equals the project cost $I$ that the creditor lent. Letting the probability that the project succeeds be $p$, the requisite sum $F$ can be derived from the following equation: $I=p F+(I-p)(y-c)$. The first term on the right-hand side of this equation is the expected value of the firm's promise to repay if its project succeeds; the second term is the expected value of the firm's promise to repay if the project fails.

Holding the project cost $I$ fixed (this is the sum the firm needs), the equation shows that the sum the firm must promise to repay creditors if solvent, $F$, will fall as the insolvency return rises. For example, if the project cost $I$ is $\$ 1000$, the failure-state firm value $y$ is $\$ 600$, bankruptcy costs $c$ are $\$ 300$, and the probability of success $p$ is .7 , then the amount the firm must promise to repay, $F$, is $\$ 1300$ to borrow $\$ 1,000$ (an effective interest rate of $30 \%$ ). If the firm's failure-state value were to increase to $\$ 800$ or bankruptcy costs were to fall to $\$ 100$, then $F$ would fall to $\$ 1241.29$ (an effective interest rate of $21 \%)$.

A bankruptcy system would increase the value of the firm in the failure state by solving the creditors' coordination problem-that is, by ensuring that insolvent firms are not always liquidated. Bankruptcy value would also increase were the state only to reorganize firms whose going-concern values

26. See Douglas G. Baird, THe Elements of Bankruptcy $71-72$ (rev. od. 1993). 
exceeded their liquidation values. There are a variety of ways to reduce bankruptcy costs. A current view holds that auctioning firms to the market rather than reorganizing them best reduces these costs. ${ }^{27}$

This analysis reveals three defects of an unnecessarily costly bankruptcy system. First, firms are required to devote resources to debt finance that they might more profitably use elsewhere (i.e., firms must promise to repay too much to fund projects). Second, firms may be unable to fund some projects. A firm may have to promise creditors so much in the solvency state that doing the project is not worthwhile. ${ }^{28}$ Third, costly bankruptcy creates poor incentives for firms to maximize profits. In the example above, the project cost $\$ 1000$ but the firm must pay creditors more than $\$ 1000$ if the project succeeds. The firm thus cannot keep the full difference between project revenue and cost in the success state. Therefore, the firm will not devote effort to the project until the marginal cost of effort equals the marginal gain, but rather will devote effort until the marginal cost equals the marginal gain less the creditors' marginal share of the upside return. The more expensive debt capital is to raise (the higher $F$ is in the example above) the greater is the creditors' upside share and the lower is the firm's incentive to maximize profits. ${ }^{29}$

To summarize, in the economic view, the ultimate object of bankruptcy law is to help maximize social wealth. This object implies the instrumental goal of minimizing the cost of debt capital. This instrumental goal, in turn, is facilitated by maximizing the creditors' expected return when the firm is insolvent. Therefore, an efficient bankruptcy system maximizes the value that firms have in, and as a consequence of, the system and minimizes the costs of realizing that value.

\section{Challenges to the Economic View}

Participants in the debate about what bankruptcy systems should do sometimes characterize themselves as either "free marketers" or "traditionalists." 30 Much of the debate is characterized by an "ought/is" mistake. Free marketers claim that bankruptcy should pursue only goal $x$; traditionalists respond that the Bankruptcy Code in fact pursues goals $y$ and $z$ as well. ${ }^{31}$ This response is a mistake because the appropriate response to an

27. The earliest statement of this view is Douglas G. Baird, The Uneasy Case for Corporate Reorganizations, 15 J. LEGAL STUD. 127 (1986). A more complex auction scheme is described in Phillipe A. Aghion et al., Improving Bankruptcy Procedure, 72 WASH. U. L.Q. 849 (1994).

28. This defect is stressed in the discussion below concerning contracting for bankruptcy procedures. See infra Subsection II.C.4.

29. In the costly bankruptcy example above, the firm must share $\$ 300$ of the project's upside return with creditors; in the less costly example, the firm must share $\$ 241.29$.

30. See Korobkin, supra note 23 , at 76.

31. Others have remarked on this mistake. Korobkin observes: "One of the more common responses by traditionalists to the freemarket approach has been to point directly to the reality of actual bankruptcy policy." Id. at 90. Frost states: "In essence, participants in the bankruptcy debate are speaking past one 
"ought" claim is an "ought not" claim, not an "is" claim. This Essay is concerned with justificatory claims, and in this realm the fact that the Bankruptcy Code pursues or fails to pursue a goal is relevant only in a secondorder way. That the Code pursues goal $y$ cannot imply that goal $y$ is normatively desirable, but it does indicate that $y$ is politically feasible. That the Code does not pursue goal $x$ cannot imply that goal $x$ is undesirable, but it does suggest that goal $x$ may be either politically or technically unattainable.

Turning to the debate itself, traditionalists agree that the efficiency norm is relevant to bankruptcy issues. In the traditionalist view, however, the Bankruptcy Code is a loss allocation mechanism that allocates the losses from business failure among affected parties according to particular goals, which include-but are not exhausted by-economic efficiency. ${ }^{32}$ Thus, while traditionalists also prefer bankruptcy systems to maximize the ex post value of the firm, the traditionalists additionally want these systems to protect the interests of persons or entities who do not hold current contract-based claims against the insolvent firm. ${ }^{33}$ Such persons and entities are, primarily, employees, who have an interest in future employment, ${ }^{34}$ and the congeries of interests summarized with the phrase "the community." 35 The community includes potential customers and suppliers of the firm, taxing authorities, and perhaps others. ${ }^{36}$

Two justifications are offered for protecting employees and communities. The first is loss spreading. ${ }^{37}$ Traditionalists argue that a bankruptcy system should award part of the insolvent firm's value to employees (independent of the employees' contract rights) because creditors are more able than workers

another." Frost, supra note 23, at 90.

32. Lawrence Ponoroff and F. Stephen Knippenberg typically remark that bankruptcy law allocates losses from insolvency "according to a set of principles, none of which is pre-eminent by definution." Lawrence Ponoroff \& F. Stephen Knippenberg. The Implied Good Fauh Filing Regutrement: Sentunel of an Evolving Bankruptcy Policy, 85 Nw. U. L. REv. 919.962 (1991); see also Elizabeth Warren. Bankrupicy Policy, 54 U. CHI. L. REV. 775 (1987) (suggesting a number of distributional goals besides economic efficiency).

33. See, e.g., Elizabeth Warren, Bankruptcy Policy in an Imperfect World. 92 Micu. L. REv. 336. 354. 56 (1993).

34. Arguments in favor of protecting employees are found in Jean Braucher. Bankruptcy Reorganization and Economic Development, 23 CAP. U. L. REV. 499. 517.18 (1994): Donald R. Korobkin, Employee Interests in Bankruptcy, 4 AM. BANKR. INST. L. REV. S. 26-34 (1996): and Raymond T. Nimmer, Negotiated Bankruptcy Reorganization Plans: Absolute Priority and New Value Coniributions, 36 EMORY L.J. 1009, 1032-34 (1987). Braucher adds the qualification that a banknuptcy system should not protect jobs if this would cause job loss in general but does not pursue this possibility further. See Braucher, supro, at 519. The commitment of these authors to employee protection is pallid compared to the current French bankruptcy system, which enumerates job protection as the second goal of the system and creditor payment as the third. See Richard L. Koral \& Marie-Christine Sordino. The New Banknuptcy Reorganization Law in France: Ten Years Later, 70 AM. BANKR. L.J. 437. 442 (1996).

35. See, e.g., Karen Gross, Taking Community Interests into Account in Bankruptcy: An Essay. 72 WASH. U. L.Q. 1031 (1994); Ponoroff \& Knippenberg, supra note 32, at 960; Warren, supra note 33, at 354. Warren's views have varied over time, however. She once stated. for example, that "(b)ankruplcy procedures should be evaluated in terms of whether they enhance the value of the cstalc." Elizabeth Warren, $A$ Theory of Absolute Priority, 1991 ANN. SURV. AM. LAw, 9. 47.

36. See Warren, supra note 35 , al 30.

37. See Braucher, supra note 34 , at 517-18; Nimmer, supro note 34 , at 1028. 
to protect themselves against losses from business failure in the ex ante contracts they write with the firm, or to spread those losses over the universe of borrowers. Protecting the community is justified on distributional grounds and because it allegedly internalizes the costs of business failure. ${ }^{38}$ For example, the costs of a bankruptcy fall on local suppliers as well as on creditors. If firms were reorganized to protect suppliers, the creditors, anticipating the resultant cost, presumably would make wiser lending decisions.

Traditionalists have not developed criteria to help a court or legislature decide how much of an insolvent firm's value should be devoted to protecting parties without current claims. Nor have traditionalists strongly urged particular reforms to make this protection more effective. ${ }^{39}$ Instead, traditionalists show that sections of the current Bankruptcy Code protect parties who are not creditors $^{40}$ and assert, in direct response to the free marketers, that bankruptcy should not be a one-value scheme. ${ }^{41}$

All participants in this debate about the appropriate goals of a bankruptcy system recognize that bankruptcy law affects the ability of a firm to borrow money. Thus everyone acknowledges that secured creditors should have a high bankruptcy priority (though how high is now in dispute) because otherwise some firms could not borrow. ${ }^{42}$ Traditionalists also acknowledge that a highly inefficient bankruptcy system will discourage entrepreneurial behavior. ${ }^{43}$ The current debate, however, primarily takes an after-the-fall focus, in which the emphasis is on how best to resolve the problems that arise after insolvency has occurred. This focus perhaps exists because many commentators believe that firms cannot do anything at the borrowing stage to maximize bankruptcy returns, even if the firms were free to contract. In the conventional view, giving parties this freedom would be pointless because creditor conflict and transaction costs would preclude efficient contracting. ${ }^{44}$

\section{B. Bankruptcy Law Should Protect Only Parties with Current Claims}

Two questions should be distinguished. First, should a bankruptcy system protect parties who do not have current claims against an insolvent firm?

38. See Warren, supra note 33 , at 354-56.

39. For an exception with regard to employees, see Korobkin, supra note 34, at 26-33.

40. According to Warren, the Bankruptcy Code wants "to redistribute the benefits that would stem from some creditors' collection rights to other parties who did not enjoy those rights." Warren, supra note 33 , at 355 .

41. See supra note 32 and accompanying text.

42. A sample of current scholarly views on the security interest priority may be found in Symposium, 82 CORNELL L. REV. 1279 (1997). My position is stated in Alan Schwartz, Priority Contracts and Priority in Bankruptcy, 82 CORNELL L. REv. 1396 (1997).

43. See Warren, supra note 33, at 357-58.

44. See Braucher, supra note 34, at 504-05; Thomas H. Jackson, Bankrupicy, Non-Bankrupicy Entitlements, and the Creditors' Bargain, 91 YALE L.J. 857, 862 (1982); Korobkin, supra note 23, at 119; Ponoroff \& Knippenberg, supra note 32, at 953-54; Warren, supra note 33, at 380-82. 
Second, are there good arguments in today's literature in favor of protecting these parties? This Essay answers the second question. The first question is complex, and giving a full answer to it is beyond this Essay's scope. Thus the arguments made below against protecting nonparties are directed to the burden of proof. In light of the strong arguments against extending bankruptcy protection to parties without current claims, policy analysis should be done on the assumption that facilitating the ability of firms to sell debt is the only defensible goal of business bankruptcy law. Those who believe that bankruptcy systems should perform additional functions should bring new arguments to the table. ${ }^{45}$

\section{Community Interests}

It is unnecessary for bankruptcy law to protect communities when thick markets exist. In a thick market, there are good substitutes for the firm's performance. New York City does not suffer when a boutique clothing store closes. Therefore, community protection is important only when an insolvent firm would be difficult for a community to replace. Bankruptcy law should not attempt to protect communities even in this case, however, for efficiency and equity reasons.

To understand these reasons, focus on the set of insolvent firms whose liquidation values exceed their going-concern values. All of these firms provide benefits to the communities in which they function. For a subset of the firms, these benefits exceed, in present value terms, the difference between the firms' expected costs and their revenues. A state or local government can internalize the various interests that a firm's disappearance would affect. The frequent efforts by states and localities to recruit firms and to protect domestic firms against hostile takeovers suggest that communities also can be effective in bankruptcy contexts. For example, a local community could propose a reorganization plan for a firm worth saving, under which the community pays the firm's creditors the difference between the firm's liquidation and goingconcern values and then subsidizes the firm's continued existence. Thus bankruptcy law is unnecessary to ensure that a firm will remain in its local

\footnotetext{
45. Robert Rasmussen reaches the same conclusions as this Essay does, but for different reasons. He argues that social justice requires only a bankruptcy system that efficiently maximizes creditor retums. See Robert Rasmussen, An Essay on Optimal Bankruptcy Rules and Social Justice. 1994 U. ILL L. REV. I. 42. Ronald Mann recently responded that the appropriate content of a bankruptcy system is a question of public policy, not a question of justice, but Mann does not reach final conclusions on the issues discussed here. See Ronald J. Mann, Bankruptcy and the Entillements of the Govermment: Whose Money Is It Anyway?. 70 N.Y.U. L. REV. 993, 1057 (1995). Frost argues that redistributional goals should nol be pursued in bankruptcy because bankruptcy courts are institutionally incompetent to pursue them. See Frost. supra note 23, at 122-35. This Essay takes a slightly different tack, arguing, as a substantive matter, that altempting to protect employees and communities in bankruptcy is bad public policy.
} 
community if the firm's continued existence is worth more to the community than the cost.

Now consider a bankruptcy practice of helping communities by reorganizing some firms whose liquidation values exceed their going-concern values. The efficiency objection to this practice is that the wrong set of firms will survive. Local communities know more than bankruptcy judges can know about the public benefits of saving particular firms. Therefore local communities will make more accurate continuation decisions than bankruptcy courts will. The equity objection to the practice of reorganizing firms to aid communities is that the costs fall on creditors and firms while the benefits accrue to communities. It would seem more equitable to make those who gain pay. Therefore, bankruptcy law should not attempt to protect the congeries of interests-future suppliers, landlords, etc.-that constitute "the community."

\section{Employee Interests}

To use bankruptcy systems to protect jobs is also inefficient. To see why, realize that jobs are saved when a bankruptcy system reorganizes firms whose going-concern values exceed their liquidation values. Therefore, a conflict exists between the goals of job preservation and maximizing the bankruptcy monetary return only with regard to firms whose liquidation values exceed their reorganization values. To find that liquidation value exceeds goingconcern value, however, is to find that the firm's physical assets are best redeployed in other uses. Turning to employees, a worker's human capital has two components: Firm-specific human capital, comprising skills that are more valuable to the firm than to the market generally, and general human capital, comprising skills that are worth as much to the market as to the firm. A finding that the firm's physical assets are best redeployed implies that a worker's human capital also is best redeployed: If the firm is not viable as a unit, then skills that are productive only to the firm as a unit are not worth their social costs. And it is a matter of indifference, from an efficiency point of view, where a worker's general human capital is deployed. Therefore, it is inefficient to use bankruptcy to save jobs.

There are, however, equity and efficiency concerns regarding workers whom bankruptcy displaces. Regarding equity, making workers bear the full costs of economic transitions may be objectionable from a distributional point of view. Regarding efficiency, displaced workers should move to the firms that value their services most highly, and move as quickly as possible. Both the efficiency and equity concerns today are met by unemployment insurance, which subsidizes job search, so that a worker will not have to take the first available job, and by providing workers with labor market information. Whether society now best facilitates worker redeployment is beyond this Essay's scope. Instead, two points have been made: It is inefficient to 
reorganize firms to save jobs, and society has better means than bankruptcy to solve transition problems. As an example of bankruptcy's comparative disadvantage, bankruptcy courts do not have access to local labor market information, but state unemployment offices do.

To summarize, according to the values most Americans hold, society should be concerned with the viability of local communities and with the costs of job loss. Communities, however, can and should subsidize firms whose survival is important to them, and society can respond to job loss in efficient ways while bankruptcy systems cannot. Until better arguments are brought to the table, then, the challenge to the economic goal should be rejected: Bankruptcy systems should function only to reduce the costs to firms of debt finance.

\section{E. Freedom of Contract and Bankruptcy}

Bankruptcy law can reduce the costs of debt not only by creating efficient bankruptcy systems, but also by permitting parties to contract for the systems they prefer. To begin to understand why, it is helpful to contrast bankruptcy with commercial law generally, where the concern is with ex ante rather than ex post efficiency. Commercial law has this concern because parties ordinarily can achieve ex post efficiency through renegotiation. Parties commonly write sales contracts before the state of the world in which they plan to transact is known. For example, a seller sometimes will agree to produce a product before the seller knows its actual production cost. That cost is a function of variables the seller can affect (e.g., wages) and variables the seller cannot affect (e.g., the later market price of various inputs). Similarly, a buyer sometimes will agree to purchase before the buyer knows the valuation it will place on performance. That valuation is a function of variables the buyer can control (e.g., the amount the buyer invests in the contract) and variables the buyer cannot affect (e.g., demand in the buyer's resale market). An efficient sales contract thus maximizes the parties' ex ante (or expected) utility.

This contract may turn out to be inefficient when the true state of the world is realized. As an illustration, the parties may have agreed to trade twenty units at a price $p$, but as a consequence of declining demand, it would be efficient to trade only ten units at $p$, or perhaps twenty units at a lower price than $p$. The seller in this illustration has a legal right to have the buyer take twenty units at $p$ (or have the buyer pay damages for not doing so), but because transaction costs are low, the location of this entitlement is irrelevant. The parties will modify the contract-that is, engage in renegotiation-to permit the buyer to take fewer units or to pay less (and compensate the seller for the lost profit), because the parties can split the surplus created by switching to the ex post efficient deal. Therefore, it is unnecessary for commercial law to focus on ex post efficiency. The parties have, in effect, 
chosen their own mechanism to achieve it, that mechanism being renegotiation if later events outmode the contract. Commercial law instead provides parties with default rules that, at least in theory, direct the ex ante efficient result in standard cases.

Bankruptcy law differs from other areas of commercial law because renegotiation after insolvency is difficult. Creditors cannot conveniently coordinate their collection efforts or positions respecting the appropriate disposition of the insolvent firm because there are often many creditors whose interests may diverge. ${ }^{46}$ The firm also has no legal power to compel creditors to agree. A bankruptcy system is necessary to facilitate the parties' ability to renegotiate to ex post efficient outcomes.

That bankruptcy law must be concerned with ex post efficiency cannot of itself imply the irrelevance of ex ante efficiency as a policy goal. For example, assume that different feasible bankruptcy systems would yield different renegotiation outcomes for a particular firm and its creditors. Bankruptcy law apparently should facilitate the ability of these parties to choose the bankruptcy system, and thus the renegotiation outcome, that permits the firm to borrow most cheaply. This raises the question of whether the conventional view that parties would be no better at coordinating ex ante bankruptcy bargains than they are at coordinating ex post renegotiations is correct.

\section{CONTRACTING FOR BANKRUPTCY SYSTEMS}

\section{A. A Methodological Introduction}

The content of an optimal bankruptcy system is an economic contract theory question, so readers should be introduced to the problems that this theory attempts to solve. The theory applies when either of two market imperfections obtains: hidden information or hidden action ${ }^{47}$ There is hidden information when a party does not know the "types" of its potential contract partners. For example, a seller who is considering whether to make a warranty does not know whether any particular buyer will be an intense user, and thus likely to make warranty claims, or a less intense user. The contract theory task is to identify the contract that the parties will make when one side of the market does not know the types-in this example, the different buyers' use patterns-of the other side.

This Essay analyzes a variant of the other market imperfection-hidden action. A party may take an action after making a contract that disadvantages its contract partner. Thus a firm may raise money from investors to pursue a

46. A creditor who does not agree to a renegotiation bargain can sue its debt to judgment or file a bankruptcy claim for the full amount that it is owed. This renegotiation difficulty is known as the "holdout problem." Schwartz, supra note 3, at 596-97.

47. See ANDREU MAS-COLELl ET AL., MiCroeconomic ThEORY 436-507 (1995). 
business project but divert part of the money to perks such as plush offices. This diversion will harm the investors if the probability that the project succeeds is a function of how much money is invested in it. If investors could observe the firm's ex post actions and prove in court that investing in offices rather than machines would reduce the success probability, then the contract theory problem is trivial: The optimal contract will prohibit the firm from using funds for new offices.

In the real world, the contract theory problem is not trivial for two reasons. First, investors may be unable to observe at reasonable cost how the firm is spending their money-i.e., there may be hidden action. Second, it may be very costly to write contracts that proscribe certain ex post actions and require others. To continue with the example, building nice offices is not the only way for a firm to shirk. The firm's managers might instead work less hard than they should or arrange the firm's project so that it will earn certain but lower returns relative to a more risky but optimal version. Prescribing the optimal, and proscribing every suboptimal, set of managerial actions in an investment contract would be very costly. In addition, proving in court that an action is suboptimal-for example, that the firm should have invested in, say, Venezuela rather than the United States-would be difficult and costly. When the investment contract cannot expressly require the firm to behave optimally, the contract theory problem is to identify the contract, if any, that will induce optimal actions.

This Essay asks whether parties can contract to use the bankrupicy system that is optimal in their situation. A contracting problem exists because an insolvent firm and its creditors may disagree ex post about which bankruptcy system to use. Conditional on insolvency's having occurred, the firm's managers or owners will prefer the bankruptcy system that is more likely to permit the firm to survive or to enable them to enjoy control privileges for a longer time if it ultimately fails. The creditors will prefer the system that maximizes the firm's net expected insolvency return because creditors can recover only monetary returns.

If parties can choose bankruptcy systems, and a particular firm and its creditors expect a certain system always to be optimal for them, then the contract theory problem is trivial. These parties would write a contract requiring the firm to use the efficient bankruptcy system upon insolvency. ${ }^{48}$ The contract theory problem is serious, however, because the optimality of a

48. Firms today are legally entitled to make the initual choice about which of the existing bankruptey systems to use (liquidation or reorganization), see 11 U.S.C. $\$ 301$ (1994). but a bankruplcy couri's equitable and case dismissal powers give it a de facto opportunity to overnule the firm's choice, see supra text accompanying note 10 . Courts delegate substantial discretion to insolvent firms in practice. See BAIRD \& JACKSON, supra note 25 , at 952 . A creditor coalition also is legally entitled to choose the bankruptcy system if the coalition acts before the firm does, see 11 U.S.C. $\$ 303$. but high coalituon costs ensure that firms almost always act first. Thus, the analysis here assumes that only insolvent firms choose bankruptey systems. See BAIRD \& JACKSON, supra note 25, at 89 ("[M]ost bankruptcy petitions are voluntary."). 
bankruptcy system is state-dependent: Under some values of the ex post economic parameters, it would be efficient to liquidate the firm, while under other values, reorganization would be best. Thus, a lending agreement that required the firm to use a bankruptcy system that commonly chooses reorganization might turn out to yield a suboptimal result. A relatively simple contract, apparently, could require the firm to use the "reorganization system" when certain circumstances materialize and to use another system under different circumstances. The difficulty here, as in the investment example above, is describing the circumstances. Litigation over whether firms should be reorganized or liquidated suggests that the decision is fact-specific. Describing all of the possible facts and their implications in the lending agreement would be costly.

Bankruptcy contracting, therefore, poses a difficult contract theory problem. In consequence, the model described below assumes that parties can contract over bankruptcy systems but cannot write contracts of the form: "Choose system $A$ in the following circumstances; otherwise, choose system $B$." This model supports two claims. First, a set of contracts that will induce optimal bankruptcy choices exists. Second, prohibiting parties from writing these contracts produces the bad effects described above. Firms could finance more projects if they had more freedom to contract, and they would have better incentives to maximize value.

\section{B. The Model ${ }^{49}$}

There are three obstacles to the making of bankruptcy contracts: A firm may have numerous creditors; these creditors may lend at different times; and they may have different preferences about bankruptcy systems. ${ }^{50}$ The analysis begins by assuming that all of a firm's creditors lend at the same time and have the same preferences respecting bankruptcy. On these assumptions, the obstacle of numerous creditors dissolves because the firm can offer the same contract to everyone. This part initially takes up the question of whether parties would contract about bankruptcy systems under the assumed conditions, and what the effects of banning the contracts that parties might write would be. Later, this part argues that the conclusions reached initially do not change when sequential credit extensions and heterogeneous preferences are taken into account.

A firm has a project to pursue. At a time denoted $t^{0}$, the firm attempts to borrow the project's cost in a competitive capital market. The project will begin at $t^{t}$ and the firm will repay its creditors at $t^{2}$ if the project is successful.

49. The analysis that follows is drawn from Alan Schwartz, Contracting About Bankruptcy, 13 J.L. ECON. \& ORG. 127 (1997). 866-67.

50. See Aghion et al., supra note 27 , at 850 ; Baird, supra note 27 , at 135 ; Jackson, supra note 44 , at 
If the firm is insolvent at $t^{2}$, it will choose a bankruptcy system to use at $t^{3}$. The project continues to run during the course of the system the firm chooses, and creditors are paid their bankruptcy return at $r$. Two bankruptcy systems are assumed to exist. One, denoted $R$, is the current Chapter 11 reorganization regime with two exceptions: Unlike the current regime, system $R$ strictly follows absolute priority. Also, parties are free to contract in the lending agreement for system $R$ or the other system. This system, denoted $L$, auctions insolvent firms, or the assets of those firms, to the market, distributing the proceeds strictly according to absolute priority. ${ }^{51}$

The monetary return the firm earns during bankruptcy is a function of the bankruptcy system the firm chose and the circumstances obtaining when the firm made the choice. Under some circumstances, it will be optimal for the firm to use the system $R$, and under other circumstances, $L$ will be best. Creditors can prove in court how much money the firm earned while in the bankruptcy system it chose (bankruptcy returns are "verifiable"), and the parties can observe the circumstances that exist ex post. Thus parties know after insolvency which of the two bankruptcy systems would maximize monetary returns. As in the illustrations above, however, the ex post circumstances and their relation to what an optimal bankruptcy choice would be are too costly to describe in a contract. Thus contracts of the form "Choose $R$ if certain facts obtain but otherwise choose $L^{\prime \prime}$ are excluded. ${ }^{52}$ The parties, however, can contract on the basis of a signal that correlates with the retum the firm would earn under either system. The signal may be the performance of a relevant economic index. For example, a particular firm's returns may have a high positive correlation with the Consumer Price Index (CPI). Hence, if this firm becomes insolvent when the CPI is falling, the firm probably should be liquidated. Parties are assumed to be able to prove the content of the signal in court (the CPI's performance for the most recent quarter, say). In consequence, parties in the model here may write a contract that will induce

51. A firm is reorganized when it is sold to current claimants. That is, creditors receive new equity in the firm or new forms of debt and the old equily holders recesve nothing (if absolute prionly is followed). A firm is liquidated when it is sold to the market etther as a unit or piecemeal, with the proceeds distributed to the creditors. A reorganization takes more time to conduct than a liquidation.

52. This point perhaps should be expanded. In contract theory, the relation between the circumstances that obtain and the contractual action that is optimal in those circumstances is called the "action correspondence." As an illustration, an action correspondence may require the seller to deliver 100 unis if the buyer faces high demand and 50 units if the buyer faces low demand. For the problem discussed here, the action correspondence would require the firm to choose one bankruptcy system if certann facts obtained upon insolvency and to choose the other system if other facts obtained. This Essay assumes. for the reasons given, that it would be too costly for parties to describe the action correspondence in lending agreements. As a consequence, while the parties here are assumed to know what action would be opumal ex post, their contracts, lacking an action correspondence, would not require the firm to take that action: that is, the contracts would not tell the firm to choose system $L$ in certain situations and $R$ in orters. When these directions are missing, the firm is free to choose the bankruptcy system that is provalely optumal for it. 
liquidation if the firm experiences financial distress when a signal such as the CPI is declining. ${ }^{53}$

The parties may also choose not to contract about bankruptcy in the lending agreement. In this event, the firm will either choose the system it prefers given the circumstances obtaining when it becomes insolvent, or the parties may renegotiate after insolvency. The firm is assumed to have all the bargaining power in a renegotiation because creditors have difficulty coordinating strategies after insolvency. Renegotiation, therefore, involves the firm's making an offer to creditors to use one or the other system in return for the entire marginal monetary gain that using the optimal system would create. ${ }^{54}$

To understand when parties will write contracts about bankruptcy, rely on renegotiation to induce an optimal bankruptcy choice, or let the firm choose unimpeded, it is necessary to make the conflict between an insolvent firm and its creditors more precise. Firms generate monetary returns, and their owners or managers can consume private benefits. These benefits are the pleasure or status derived from running the firm, the excess consumption of leisure while employed, and the opportunity to continue to be paid a salary. In the language of contract theory, private benefits are assumed to be unverifiable. That is, the parties cannot establish in court the monetary value of these benefits, nor can they show that the firm is consuming excessively. As a consequence, the lending agreements here, just as in the introductory investment example, cannot ban or regulate private benefits by contract. These benefits are the principal source of conflict between the firm and its creditors.

In particular, because creditors are legally entitled to the monetary return when the firm becomes insolvent, creditors want the firm to choose the bankruptcy system that maximizes monetary returns. In contrast, since after insolvency the firm legally has no claim to monetary returns, the firm prefers the bankruptcy system that permits it to consume the most private benefits. The firm makes an optimal bankruptcy choice when it picks the system that maximizes the sum of monetary returns and private benefits. ${ }^{55}$

53. Contracting on the basis of a signal is common in commercial contexts. Long-term contracts often index transaction prices to verifiable variables such as the CPI or the Producer Price Index, because tho values of the more directly relevant variables, such as a seller's costs, are difficult to establish in court. See Alan Schwartz, Relational Contracts in the Courts: An Analysis of Incomplete Agreements and Judicial Strategies, 21 J. LEGAL STUD. 271, 284-90 (1992).

54. The bargaining-power assumption is made because it is analytically convenient and also because it is realistic to endow the firm with considerable bargaining power ex post. If the bargaining-power assumption is relaxed to give creditors a share of renegotiation rents, then renegotiation would become a more attractive alternative relative to ex ante contract than the text above permits, but none of the analytical results would change.

55. Contracts that permit creditors rather than the firm to choose the bankruptcy system are not considered. As stated above, creditor coalition costs after insolvency often would make it difficult for creditors jointly to enforce a contract. See supra note 48 . In addition, supposing that private benefits should count in a utility calculus, letting creditors choose the bankruptcy system could be inefficient. Creditors always will choose the system that maximizes monetary returns. A system may do this in a particular case 
When a certain state of the world obtains ex post that is denoted $\theta_{L}$, it is assumed to be optimal for the parties to use the bankruptcy system $L$; this system would maximize the sum of monetary returns and private benefits for these parties. When the second possible state of the world obtains ex post, denoted $\theta_{R}$, it will be optimal to use system $R$. Thus, a firm that makes optimal bankruptcy choices will choose system $L$ when state $\theta_{L}$ obtains, and will choose system $R$ when state $\theta_{R}$ obtains. The parties know the probability that one or the other of these ex post states will materialize.

The private benefits that the firm can obtain derive from continuing with its project. These benefits are likely to be greater under bankruptcy system $R$ because this system prefers reorganization and thus permits the firm to survive intact for a longer period. It is assumed that the firm derives greater private benefits from system $R$ whichever state of the world obtains ex post-i.e., the firm will always choose system $R$ unless it is constrained by ex ante contract or by ex post renegotiation.

Recall that choosing system $L$ when state $\theta_{L}$ obtains maximizes the sum of monetary returns and private benefits. If the firm nevertheless obtains greater private benefits from choosing system $R$ even when the circumstances summarized by $\theta_{L}$ obtain, it must follow that monetary returns are maximized by system $L$ given $\theta_{L}$. As a consequence, when state $\theta_{L}$ does obtain ex post, the insolvent firm and its creditors will be in conflict: The firm will prefer system $R$-i.e., want to reorganize-but the creditors will prefer system $L$-i.e., want to liquidate. Moreover, if the firm is unconstrained, it will inefficiently choose system $R$. In contrast, the parties' preferences are in harmony when state $\theta_{R}$ obtains. The firm will prefer to choose system $R$ then, and because $R$ in this case generates greater monetary returns than $L$, the creditors will prefer $R$ as well. The parties' contracting problem thus is to induce the firm to choose bankruptcy system $L$ when the ex post state of the world $\theta_{L}$ obtains.

Before seeing how this problem can be solved, a general description of the parties' incentives and circumstances should be completed. All of the parties are assumed to be risk neutral. Creditors care only about monetary returns, but the firm cares about these and private benefits because the two are substitutes; a lending agreement can compensate the firm with money to forgo private benefits. The creditors' expected return under any lending agreement is zero, because credit markets are assumed to be competitive. Finally, the firm's

but not maximize the sum of monetary retums and private benefits. An insolvent firm is eash constranned (by definition) and so may be unable to bribe creditors to choose the system that is optumal all things considered when creditors prefer the system that maximizes only monetary retums. Part III argues that a firm's private benefits should not count in a bankruptcy policy analysis, but it is still unnecessary to analyze contracts that permit creditors to choose the system. Paries would use creditor-control contracts (if al all) when these contracts would be superior to firm-control contracts. The showing made below, that permutiing parties to make the latter contracts will enhance efficiency. implies that parties also should be permitted to make creditor-control contracts. 
managers represent the shareholders' interests perfectly. ${ }^{56}$ The timing of the game is illustrated in Figure 1.

\section{FIGURE 1}

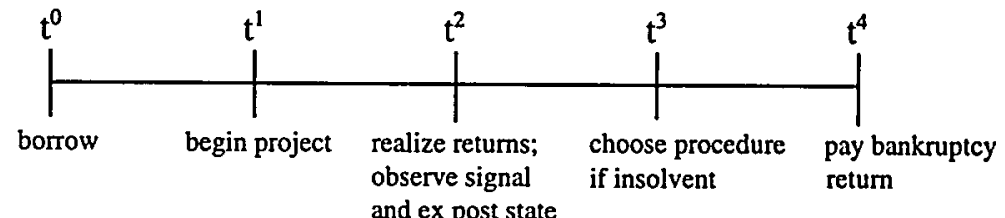

In this model, firms bear the consequences of choosing inefficient bankruptcy systems. Creditors plausibly expect firms to choose suboptimally some of the time. This expectation lowers the creditors' anticipated insolvency return, and because creditors earn zero profits, they must then require firms to repay higher sums when projects succeed. Firms have an incentive to offer lending agreements to creditors that minimize the moral hazard risk. A firm, however, cannot simply promise to use the efficient bankruptcy system (to choose system $L$ when ex post state $\theta_{L}$ obtains) because the circumstances that make a system optimal cannot be described in a contract. Can the firm otherwise make a credible commitment to choose optimally ? $^{57}$

\section{Bankruptcy Contracts}

A firm has three contractual choices in the situation modeled here. First,

56. Agency costs are assumed to be zero, not because they are zero in fact, but because this Essay focuses on the conflict regarding insolvency that exists between the firm and its debt investors. Shareholders have a variety of ways to reduce agency costs, including the costs that are manifested in insolvency contexts, but the shareholder-manager conflict is beyond this Essay's scope. A more serious restrictive assumption is that the firm cannot collude with one set of creditors to injure the others. As with the zero agency costs assumption, this assumption does not always describe the world accurately. When potential creditors anticipate collusion, many terms in a lending agreement will be affected, and some parties may not lend at all. Collusion is a sufficiently complex and serious subject to deserve separate treatment. For an interesting analysis, see Robert Gertner \& David Scharfstein, A Theory of Workouts and the Effects of Reorganization Law, 46 J. FiN. 1189 (1991).

57. The situation modeled here is realistic. Though the data are sparse, apparently a little more than a third of insolvent corporations that file for bankruptcy choose the Chapter 11 reorganization process, see Samuel L. Bufford, What Is Right About Bankruptcy Law and Wrong About lts Critics, 72 WAStI. U. L.Q. 829,832 (1994), but a very large fraction of these Chapter 11 reorganizations are ultimately dismissed, and the firms are then liquidated, see 1 NATIONAL BANKRUPICY REvIEW COMMISSION, supra note 4, at 610. Bankruptcy courts nevertheless dismiss too few Chapter 11 petitions. A recent study showed that over $40 \%$ of firms emerging from Chapter 11 experience operating losses in the three years following bankruptcy, and $32 \%$ of reorganized firms either reenter bankruptcy or restructure their debt. See Edith Shwalb Hotchkiss, Postbankruptcy Performance and Management Turnover, 50 J. FIN. 3, 4 (1995). Insolvent firms today thus appear often to choose bankruptcy systems that are inefficient in their circumstances. Bccause creditors have rational expectations, firms ex ante bear the consequences of later strategic behavior. Unlike in the model above, however, current firms cannot legally commit to behave nonstrategically. 
it can offer creditors a "renegotiation-proof" contract that will induce the firm to choose the optimal bankruptcy system in the event of insolvency. The contract is called renegotiation proof because no party will have an incentive to propose changes in it in light of later events. Second, the firm can offer creditors a contract that does not deal with bankruptcy. In this case, the parties rely on renegotiation to induce the optimal bankruptcy choice. Third, the firm can offer a contract that conditions the bankruptcy choice on a signal that correlates with the firm's ex post circumstances. Parties will have an incentive to renegotiate this contract when the signal inaccurately indicates that state $\theta_{R}$ will obtain, but state $\theta_{L}$ obtains instead, so this contract is called "partially renegotiation proof." The firm will offer creditors the contract that maximizes the creditors' expected insolvency return because this will maximize the amount the firm can borrow.

\section{Renegotiation-Proof Contracts}

The firm must be bribed to choose optimally because it cannot be required to choose optimally. A renegotiation-proof contract bribes the firm by permitting it to keep $s \%$ of the insolvency monetary return no matter which bankruptcy system the firm chooses. The firm does better monetarily if it chooses the system that maximizes monetary returns, but the firm also wants to consume private benefits. Hence, the percentage $s$ must be high enough so that the firm will do better all in all when it makes the optimal choice of a system.

To see how the percentage $s$ is set, recall that the object is to induce the firm to choose bankruptcy system $L$ when insolvency state $\theta_{L}$ obtains. Denote the firm's monetary return when it does choose $L$ in this case as $y_{L L}$ and the firm's monetary return when it inefficiently chooses system $R$ as $y_{L R^{*}}{ }^{38} \mathrm{Also}$, denote the firm's private benefits when it chooses system $L$ in state $\theta_{L}$ as $b_{L L}$, and its private benefits when it inefficiently chooses system $R$ as $b_{L R}$. If the firm must do better all in all choosing system $L$ when $\theta_{L}$ obtains, the following inequality must be satisfied:

$$
s y_{L L}+b_{L L} \geq s y_{L R}+b_{L R} \text {. }
$$

Recall that $s$ is the percentage share of the insolvency monetary return that the contract permits the firm to keep. The first term on the left-hand side of this inequality is the firm's monetary payoff from choosing the optimal bankruptcy

58. Respecting the notation, the monetary retum is denoted $y$. The first subscripted captal letter denotes the ex post state, and the second capital letter denotes the firm's choice of a bankruptcy system. Thus, $y_{L L}$ denotes the monetary retum that is generated when the set of insolvency circumstances summarized by $\theta_{L}$ occurs and the firm chooses bankrupicy sysiem $L$, and $y_{L x}$ denotes the monetary return in state $\theta_{L}$ if the firm inefficiently chooses system $R$. 
system $L$ in state $\theta_{L}$, and the first term on the right-hand side is the firm's monetary payoff if it chooses suboptimally. The second term on the left-hand side represents the private benefits the firm realizes if it chooses the efficient system $L$ in state $\theta_{L}$, and the second term on the right-hand side represents the larger private benefits the firm would obtain from choosing the suboptimal system. The left-hand side of the inequality will exceed the right-hand side if the firm's share of the relatively high monetary return from choosing optimally makes up for the lower private benefits of accepting liquidation.

Solving this inequality for $s^{*}$, the optimal bribe, yields

$$
s^{*}=\frac{b_{L, R}-b_{L, L}}{y_{L, L}-y_{L, R}} .
$$

This equation shows that the optimal bribe is lower when the firm cannot realize significantly greater private benefits from choosing wrongly $\left(b_{L, R}-b_{L, L}\right.$ is small), and when the marginal monetary return from choosing correctly is large $\left(y_{L L}-y_{L R}\right.$ is big). The reasoning underlying the former result should be obvious. As for the latter, when the marginal return from choosing optimally is large, the firm needs to be given a smaller share of it to induce good behavior. 59

An immediate implication of this analysis is that the possibility of moral hazard can prevent the firm from financing some projects. If the firm must be given a share of the bankruptcy return to induce optimal behavior, the firm can credibly promise to repay less money when insolvent than it could promise to repay if the firm always behaved optimally. The lower the creditors' insolvency payoff, the less they will lend and some positive value projects that would be funded if creditors could directly control the firm will not be funded when the firm must be bribed. The extent of the inability of a firm to fund good projects and the contribution of bankruptcy contracts to reducing it is best shown by illustration. ${ }^{60}$

59. To clarify further what is going on, the firm can predict the private benefits that it later may realize in bankruptcy and its expected monetary return. As a consequence, the firm can calculate the optimal bribe $s^{*}$ to include in the contract. The firm will offer creditors a contract with a bribe of $s^{*}$ when this contract would maximize the creditors' expected insolvency-state return. This contract is enforceable because the actual monetary return is verifiable and a court can learn the specified fraction $s^{*}$ from the contract. Thus, if the firm does offer creditors a renegotiation-proof contract, the court later will award the firm $s^{*}$ percent of the monetary return the firm earned in the bankruptcy system it chose. The creditors may not be able to observe the firm's private benefits, and private benefits are not verifiable by a third-party decisionmaker. Therefore, the parties cannot write contracts that make the requisite bribe partly a function of the private benefits the firm could consume in either bankruptcy system.

60. The contracts that are considered here do not make the percentage of the monetary retum the firm is permitted to keep-the bribe-a function of the system the firm chooses. More complex contracts sometimes would vary the bribe with the selected system. It is unnecessary to consider these contracts here. If banning simple contracts is inefficient, as shown below, it follows that banning the possibly more optimal complex contracts is inefficient as well. 
The examples that follow assume that the firm has available to it a project that will return $\$ 260$ if it succeeds. If the project fails, and if reorganization would be optimal, the monetary reorganization return would be $\$ 180$; if liquidation would be optimal upon project failure, the liquidation return would be $\$ 120$. The probability that the project succeeds is .8. In the event of failure, the probability that reorganization will be optimal is .3 . The reorganization probability is chosen to be relatively low because it is often efficient to liquidate failed firms. If the firm always voluntarily chose the optimal bankruptcy procedure without being bribed, the project would have an expected value of

$$
E(R)=.8 \times \$ 260+.2 \times(.3 \times \$ 180+.7 \times \$ 120)=\$ 235.60
$$

The first term on the right-hand side of this equation is the expected value of the firm's solvency return; the second term is the expected value of the insolvency return if the firm efficiently chooses system $R$ in $\theta_{R}$ and system $L$ in $\theta_{L}$. The project's expected return would then be $\$ 235.60$, and the project would have a positive net present value if it cost less than this to do. In this model, however, the firm sometimes will make a suboptimal choice of a bankruptcy system (it will choose system $R$ when $L$ would be efficient), and this will cause the project's expected return to fall below $\$ 235.60$.

To see how a bankruptcy contract could respond to this problem, let the firm obtain private benefits of $\$ 40$ if state $\theta_{L}$ were to obtain and the firm were to choose bankruptcy system $L$, and let the firm obtain private benefits of $\$ 70$ if it were to choose system $R$ instead. The firm would thus choose $R$ unless it were paid not to do so. Also, if the firm inefficiently chose system $R$ when $\theta_{L}$ obtained, the monetary return from reorganization would fall to $\$ 30$. Using the equation for $s^{*}$ set out above, on these values for the parameters, the firm would have to be paid one-third of the bankruptcy return in order to induce an optimal bankruptcy choice. This bribe reduces the amount available to creditors in the insolvency state, with the result that the firm can promise to repay creditors at most $\$ 226.49 .{ }^{61}$ Hence, if the firm's project costs between $\$ 226.50$ and $\$ 235.59$, it could not be financed.

This example teaches two lessons. First, a renegotiation-proof contract exists that will induce the firm to choose the efficient bankruptcy system. The contract is renegotiation-proof because the firm does better choosing

61. When the firm keeps one-third of the insolvency monetary return and will thus choose the optimal system, the maximum expected return available for creditors becomes

$$
E(R)=.8 \times \$ 260+[0.67 \times .2 \times(.3 \times \$ 180+.7 \times \$ 120)]=\$ 226.49
$$

The terms in brackets reflect the firm's choice of the optimal bankruptcy system, but the monetary return that creditors receive must be multiplied by two-thirds bocause the firm is given one-third of that retum as an inducement to choose optimally. 
efficiently and being bribed than choosing inefficiently. Because the contract always induces the firm to choose optimally, the creditors' return is maximized as well and no one has an incentive to renegotiate. Instead, after insolvency the firm will choose the optimal bankruptcy system, and because the contract is enforceable, the court will permit the firm to keep the contractually specified fraction of monetary returns that the system generates. The second lesson is that there can be underinvestment even with free contracting: The firm may be unable to finance a positive value project because of moral hazard. ${ }^{62}$

\section{Renegotiation Contracts}

The firm also could offer creditors a contract that does not deal with bankruptcy. Such a contract would not pay the firm a bribe to choose the optimal bankruptcy system (i.e., $s^{*}=0$ ). If state $\theta_{R}$ obtains upon insolvency, the firm would choose system $R$ voluntarily for the reasons given. Because the bribe then is zero, creditors could keep the full monetary return that using the optimal system would generate. On the other hand, if state $\theta_{L}$ were to obtain, the firm would also choose system $R$ unless the creditors bribed it in a renegotiation to choose the optimal system $L$. It is assumed here that the firm has all the bargaining power and so could capture the entire marginal return from making an efficient bankruptcy choice. In the example here, that would be the difference between the optimal-state $\theta_{L}$ liquidation return and the suboptimal-state $\theta_{L}$ reorganization return $(\$ 120-\$ 30=\$ 90)$. On the values for the parameters here, such a renegotiation contract would produce an expected gain for creditors of

$$
E(R)=.8 \times \$ 260+.2(.3 \times \$ 180+.7 \times \$ 30)=\$ 223.00 .
$$

The first term within the parentheses indicates that creditors keep the entire monetary return when state $\theta_{R}$ materializes and the firm voluntarily chooses system $R$; the second term reflects the firm's ability to keep the entire renegotiation rent (the $\$ 90$ ) should state $\theta_{L}$ occur.

\section{Partially Renegotiation-Proof Contracts}

A partially renegotiation-proof contract would condition on a signal that correlates with the firm's insolvency-state circumstances. Denote this signal $v$

62. Investment is suboptimal compared to the case when creditors know and can prove in court what the firm's efficient bankruptcy choice should be. The more relevant question, since information seldom can be made this perfect, is whether a particular contract is "constrained efficient": Does the contract produce the best result given the verifiable information that parties can be expected to have? Answering this question for the example in the text requires an analysis of the firm's contractual alternatives. 
and assume that a high value for $v$ signals an increasing probability that the firm is in state $\theta_{R}$, in which the firm would choose the optimal bankruptcy system voluntarily, while a low value for $v$ signals an increasing probability that the firm is in $\theta_{L}$, in which it would have to be bribed to choose optimally. A partially renegotiation-proof contract would pay a bribe of zero if a high value for $v$ is observed when the firm becomes insolvent and a bribe of $s_{v}^{*}>0$ if a low value for $v$ is observed. The parties will renegotiate this contract only if a high value for $v$ is observed, but $\theta_{L}$ surprisingly occurs. In this case, because the contract pays no bribe, the creditors must renegotiate to induce the firm to choose the efficient bankruptcy system.

Partially renegotiation-proof contracts do best when the signal is highly informative. In this event, the parties will seldom have to renegotiate in the state $\left(\theta_{\nu}\right)$ when renegotiation would maximally disadvantage creditors. To see how such a contract would work, retain all of the values set out above, and let $\lambda_{R}$ be the probability that the firm is in state $\theta_{R}$ when $v_{\text {high }}$ is observed, and $\lambda_{L}$ be the probability that the firm is in state $\theta_{R}$ when $v_{\text {low }}$ is observed. Assume that the signal is highly informative: $\lambda_{R}=.9$ and $\lambda_{L}=.1$. Then, using the values in the examples above, the creditors' return under a partially renegotiation proof contract is $\$ 235.30 . .^{63}$ This contract almost replicates the full information result: Under the contract, the firm would only be unable to finance projects that would cost between $\$ 235.31$ and $\$ 235.60$.

\section{The Effect of Preventing Parties from Writing Bankruptcy Contracts}

The legal prohibition on contracting for bankruptcy systems is inefficient because the ban requires parties always to use "renegotiation contracts" even when other contracts would generate higher expected values for creditors. ${ }^{64}$ Table 1 illustrates the maximum value that the firm could promise to creditors if it could always voluntarily commit to choosing optimally and under the three contracts considered above.

63. The creditors' expected retum under a partially renegotiation-proof contract is $q z+(1-q)\left\{p_{R}\left[\lambda_{R} y_{R R}+\left(1-\lambda_{R}\right)\left(1-s_{0}^{*}\right) y_{\gamma_{R}}\right]+p_{L}\left[0+\left(1-\lambda_{L}\right)\left(1-s_{*}^{*}\right) y_{L}\right]\right\}$.

64. The unique equilibrium that occurs when bankrupley contracts are unenforceable resules in parties not writing these contracts. To see why, assume that parties use the renegouation-proof contract described above, which pays the firm one-third of the total bankruptcy monetary retum to choose the opumal system. When this contract does not legally bind, a creditor has the right to ignore the deal and file a bankruptcy claim for the full amount that it is owed rather than two-thirds of that amount. If the firm actually chose the system that maximized monetary returns and creditors generally adhered to the contract. a paricular creditor could increase its bankruptcy payoff by exercising its legal right to claim the full amount it is owed. Since many creditors would reason in this way. many full claims would be filed, and there would not be enough left to pay the firm's bribe. Anticipating this, the firm itself would ignore the contract and choose the system that maximized its private benefits. And anticipating this, in tum. creditors would not agree to bankruptcy contracts. 
TABLE 1

\begin{tabular}{||l|l|}
\hline Voluntary Optimal Choice & $\$ 235.60$ \\
\hline Partially Renegotiation-Proof Contract & $\$ 235.30$ \\
\hline Renegotiation-Proof Contract & $\$ 226.49$ \\
\hline Renegotiation Contract & $\$ 223.00$ \\
\hline
\end{tabular}

Current law will not enforce the first two contracts, which pay bribes to induce firms to make optimal bankruptcy choices. The law forces parties to use the renegotiation contract, which is silent about bankruptcy, relying instead on ex post renegotiation to achieve efficient choice. The table above shows that parties would sometimes eschew renegotiation contracts in favor of one or the other bankruptcy contract if they had a choice. The legal ban on free contracting exacerbates the underinvestment problem: Firms today cannot finance projects that they would be able to finance if the ban were repealed.

The ban additionally worsens firms' incentive to maximize project value. Because firms cannot contract for bankruptcy procedures, they sometimes cannot offer contracts to creditors that maximize the creditors' insolvency payoffs. Consequently, firms must pay too much for debt capital when projects are funded. When firms must share part of the upside return with creditors, they will not invest effort until marginal cost equals marginal gain. ${ }^{65}$

\section{The Choice Between Renegotiation and Contract}

Despite the numerical comparison above, parties will sometimes prefer the renegotiation contract. This preference exists when the expected value of choosing reorganization-system $R$-in the "reorganization state" is high. Reorganization will have a high expected value when there is a high probability that the reorganization state will occur or when the payoff in it will be high relative to the liquidation return. A renegotiation contract maximizes the creditors' expected insolvency return when these conditions obtain because the firm will choose reorganization voluntarily; it need not be bribed. Consequently, creditors could appropriate the entire (high) reorganization return, and this is better for them than a contract that would pay the firm a bribe to choose optimally no matter which ex post state occurred. Conversely, when the probability that the firm will be in the "liquidation state" is high, or that the liquidation return will be high relative to the reorganization return,

65. A good bankruptcy system is said to discipline managers because managers who shirk or otherwise perform badly lose their jobs. See Aghion et al., supra note 27, at 852 . The ban on contracting for bankruptcy procedures is inconsistent with this goal because the ban induces shirking. 
creditors do better under a contract that bribes the firm to choose the liquidation system $L$. Such a contract reserves to creditors some fraction of the liquidation return, while if the parties had to renegotiate to system $L$ ex post, creditors would get none of this return. Hence, the current ban on bankruptcy contracts bites only in some cases.

\section{Barriers to Bankruptcy Contracts}

The conclusion that it is inefficient to ban contracting for bankruptcy systems would have only theoretical interest if practical obstacles prevented parties from writing bankruptcy contracts. One possible obstacle to writing these contracts is that a firm may have many creditors. This obstacle is not serious, however, because the firm can offer contracts to creditors, and it would offer to all creditors the efficient contract with respect to bankruptcy. A possibly more serious obstacle is an intertemporal coordination problem because creditors sometimes lend at different times while the parameters that determine which contract would be optimal can be time variant. ${ }^{\infty}$ Another possibly serious obstacle is that a firm's creditors may have inconsistent preferences concerning bankruptcy systems. If so, there is no contract to which everyone will agree. This section argues that parties could overcome these barriers with some help from the law. Because bankruptcy contracts are currently illegal, there is no data about real contracts that could support this argument. The goal here is to render plausible the view that bankruptcy contracting would occur if it were permitted.

\section{Intertemporal Coordination}

A set of contracts exists that will achieve the results described above even though creditors lend at different times. ${ }^{67}$ To describe these contracts, let a firm have two creditors, with the first arriving at $f$ as in the model in Section III.B. Assume that it is optimal at $\rho$ to use a renegotiation-proof contract that would pay the firm $s^{*}$ of the bankruptcy return to choose the optimal

66. Whether liquidation or reorganization would be optimal, for example, could depend on the business cycle. If the debtor's industry is depressed, then sales to the market may bring low returns and be hard to finance, implying that reorganization would be optimal. Liquidation may be best when tumes are good. Thus a bankruptcy contract that induced liquidation could become outmoded by events. In contrst. if a liquidation contract remains optimal, it is argued below that the optumal bribe seldom would vary matenally over time.

67. The parties are assumed to be symmetrically informed about expected and actual project retums and the realized state of the world. If parties were asymmetrically informed. creditor collusion might be easier to attain. It is plausible to assume symmetric information for two reasons. First, al the contracting stage all values are expected (the possible retums that system $R$ could generate in $\theta_{k}$, for example). If the parties know only the distribution of possible retums, which is plausible. they can write bankruptcy contracts: Assuming the parties are risk neutral, the contracts will use the means of the distributions. Second, at the payoff stage, the particular bankruptcy procedure will have run its course and the results will then be known. 
bankruptcy system. The initial creditor has an incentive to sign this contract, though the parameters that determine the optimal bribe may vary over time. This is because in an efficient market, the best estimate of the value that $s^{*}$ will take at $t^{2}$, when bankruptcy-relevant variables are finally realized, is the value for $s^{*}$ when estimated as of $t^{068}$ The firm can ensure the initial creditor's consent to the renegotiation-proof contract by offering two "conversion terms" that will update the creditor's contract as later creditors arrive.

To see how these conversion terms would work, assume that a second creditor arrives at $t^{l}$ and that it remains optimal to use a renegotiation-proof contract. The lending agreement between the firm and the second creditor will provide that a bribe is to be paid that will be determined by the expected values of the parameters as of time $t^{\prime}$. The second creditor will sign the contract because the agreement will ensure it a normal return. The first conversion term in the contract with the initial creditor will provide that if the bribe that the time $t^{l}$ parameters imply differs from the bribe that the $t^{0}$ parameters implied, the bribe in the first contract will convert to the bribe in the second contract. The first creditor would agree to a contract with this feature because the optimal bribe for it will not vary in expectation, and also because the initial creditor always wants the firm to make an optimal bankruptcy choice. The conversion term also ensures that the firm's contracts will be consistent: As of bankruptcy, all contracts will have the same bribe.

There may seem to be more cause for concern if the type of lending agreement that turned out to be optimal at $t^{l}$ differed from the contract that initially was optimal. For example, suppose that the parameters at $t^{\prime}$ imply a renegotiation contract rather than the renegotiation-proof contract that the first creditor signed. The firm wants to offer its second creditor the currently optimal contract. Consistency among the firm's contracts can be achieved with a second conversion term, which provides that the initial creditor's contract will convert (only as regards bankruptcy) to the contract type that is currently optimal for the firm. If it becomes optimal for the firm to offer the second creditor a renegotiation contract, the initial creditor's contract will convert to a renegotiation contract as well. The initial creditor would agree to a contract with this conversion term because the firm would switch contracts only if the new contract would give creditors a greater expected return than the old. The firm would offer the conversion term because it benefits from the flexibility to switch contracts as economic conditions change.

A possible objection to these results is that, as regards the renegotiationproof contract, the firm would strategically not lower the optimal bribe $s^{*}$ in a contract with the later creditor, though circumstances made a lower bribe

68. Put formally, the estimated value of the optimal bribe equals the expected value at $f$ plus an crror term with mean zero: $E\left(s^{*}\left(t^{2}\right)\right)=s^{*}\left(t^{0}\right)+\epsilon$, where $E(\epsilon)=0$. 
efficient. The disincentive to lowering $s^{*}$ in a contract with the later creditor is that the conversion feature would require lowering $s^{*}$ for the initial creditor as well. The firm would sometimes do better, the objection goes, with the higher bankruptcy return that a higher $s^{\circ}$ in all contracts yields than with a set of sequentially efficient contracts. This form of strategic behavior would result in the firm's being paid more upon insolvency to choose the optimal system than would be strictly necessary to guarantee optimal choice; but this is only a wealth transfer. Strategic behavior would be a concern, however, if the initial creditor anticipated it and refused to sign a bankruptcy contract. The initial creditor might reason that the firm would always trigger the conversion feature when the optimal bribe rose, but not always trigger it when the optimal bribe fell. As a consequence, $s^{*}$ would be systematically biased upward, but in a magnitude that would be hard to anticipate. A creditor that expected the bribe to rise unpredictably might be reluctant to sign a bankruptcy contract.

This form of strategic behavior would be rare for two reasons. First, the optimal bribe typically would not change with time. To see why, recall the expression for $s^{*}$ :

$$
s^{*}=\frac{b_{L R}-b_{L L}}{y_{L L}-y_{L R}} .
$$

The optimal bribe would change if the firm would consume relatively more or fewer benefits in an inefficient reorganization than originally thought ( $b_{L R}-b_{L L}$ changes), or the relative monetary attractiveness of liquidation over reorganization, conditional on liquidation being efficient, unexpectedly varies $\left(y_{L L}-y_{L R}\right.$ changes). Respecting the former, the most likely cause of a change in private benefits is a change in the firm's scale: There are more private benefits from running large firms than small firms. The firm borrows from the later creditor (incurs later credit) in the model here while it is still solvent. The private benefit difference would shrink ( $s^{*}$ would fall) if the firm was materially smaller at $t^{\prime}$ than at $t$, but it is hard to reconcile such shrinkage with solvency. More likely, the firm would be at approximately the same scale when it borrows again.

The optimal bribe would also fall if the relative financial attractiveness of liquidation increased, but it is hard to see how that would happen. Liquidation is relatively more attractive than reorganization when the firm has assets that are worth almost as much to the market as to the firm-ihe firm's capital is primarily physical. Hence, if the firm's second project unexpectedly differed substantially from the first-e.g., a computer software firm surprisingly started a machine tool business - then liquidation would generate relatively more financial gain than reorganization ( $s^{*}$ would fall). This prospect is also unlikely 
because firms tend to do related things (the software firm might borrow later to finance the development of a new computer program). Firms, therefore, would seldom have an incentive to engage in the strategic behavior described above because the optimal bribe is unlikely to fall materially in the period while the initial credit extension remains unpaid and the firm borrows more money.

The firm would also probably not behave strategically because the behavior can be unprofitable. The gain to the firm from strategic behavior is a higher bankruptcy payoff. The loss stems from the firm's having to offer an inefficient contract to the second creditor, thus not maximizing this creditor's insolvency payoff. The second creditor, therefore, will lend less money. As a result, the firm would have to do its later project on an inefficiently small scale or devote resources to financing the project that could be used elsewhere. The bankruptcy gain must be weighted by the probability of insolvency and the financing loss by the probably much higher probability of solvency. Also, solvency returns are higher in absolute terms than insolvency returns. Therefore, the expected costs to the firm of offering later creditors inefficient contracts apparently would often outweigh the gains.

To summarize, the presence of numerous creditors that lend at different times would not preclude bankruptcy contracting. The large numbercoordination barrier would fall because the firm deals with everyone and so can coordinate bankruptcy contracting. The intertemporal coordination barrier would fall because a set of sequentially efficient contracts respecting bankruptcy exists. This set of contracts would be strategy-proof in the usual case.

\section{Creditor Conflict}

Creditors care only about monetary returns and so would be able to agree upon contracts that induce firms to choose bankruptcy systems that maximize monetary returns. Such agreement seldom could be achieved today, however, because the current U.S. bankruptcy system does not respect absolute priority. Instead, the liquidation system (Chapter 7) respects absolute priority much more than the reorganization system (Chapter 11) does. In Chapter 7, a trustee commonly is appointed whose task is to convert the bankrupt estate into cash and pay the cash to creditors. The firm has no power to influence this process. In contrast, firms operate under their current management during the pendency of a Chapter 11 reorganization and can manipulate the process to shift wealth to themselves. ${ }^{69}$ As a consequence, senior creditors today commonly prefer

69. Section 1107 of the Bankruptcy Code permits the debtor to operate the firm during the pendency of the reorganization and $\S 1121$ (a)-(c) gives the debtor the exclusive right to file a reorganization plan during the first 180 days of the proceeding. See 11 U.S.C. $\$ \S 1107,1121$ (a)-(c) (1994). It is widely believed that debtor firms use their power to run their businesses and to control the reorganization agendas 
firms to use Chapter 7, whether liquidation would be efficient or not, while junior creditors commonly prefer firms to use Chapter 11, whether reorganization would be efficient or not. The creditors in the model here would have similarly conflicting preferences over systems $L$ and $R$ if they expected the two systems to vary in the order in which they paid claims, and this conflict would make bankruptcy contracts hard to write. The model assumes this conflict away by supposing that systems $R$ and $L$ both pay claims strictly in order of priority. There is, therefore, an additional normative reason to prefer bankruptcy systems that respect absolute priority: If every system in the choice set does this, a large barrier to writing bankruptcy contracts would be removed.

There may be two other sources of creditor conflict. To understand the first of these, it is helpful to begin by assuming that all creditors would be paid pro rata. Under this distributional rule, each creditor receives a sum that is determined by multiplying the firm's bankruptcy return by a fraction that is the ratio of the particular creditor's claim to the firm's total indebtedness. The amount the creditor lent and the firm's total debt are fixed when bankruptcy occurs, and thus the ratio that determines what the creditor receives is also fixed. Given a fixed payout ratio, the variable that is relevant to the creditor is the firm's monetary return during the bankruptcy procedure. This analysis implies that when creditors are paid pro rata, there is no creditor conflict: Every creditor wants the firm to choose the bankruptcy system that maximizes the monetary return.

This preference would continue to exist in most cases if the firm's creditors ranked unequally. If absolute priority is respected, junior creditors would prefer the firm to choose the system that maximizes the monetary return, because they are paid nothing until claims senior to theirs are paid in full. ${ }^{70}$ Turning to senior claimants, a senior claimant would also prefer the firm to choose the optimal procedure if it would be paid less than in full under

to capture portions of the value that creditors are legally entitled to receive. A theoretical analysis of how debtors manipulate the s atute is Lucian Ayre Bebchuk \& Howard F. Chang. Bargaining and the Diviston of Value in Corporate Reorganization. 8 J.L. ECON. \& ORG. 253 (1992). Suppon for the theory is found in the frequent violations of absolute priority in reorganizations, see. e.g.. Allan Ebertart et al.. Securrty Pricing and Deviations from the Absolute Priorin Rule in Bankruptcy Proceedings. 45 J. Fin. 1457 (1990); Lawrence A. Weiss, Bankruptcy Resolution, 27 J. FIN. ECON. 285 (1990). and in credible evidence of managerial self-dealing, see Stuart C. Gilson et al., Valuation of Bankrupt Firms (Nov. 1997) (unpublished manuscript, on file with the Yale Law Joumal).

70. Denote the firm's monetary return under a bankruptcy system as $y_{0}$, where $t$ is either system $R$ or system $L$. Assume that the firm has two creditors, one of whom is senor to the other. The senor creditor's bankruptcy payoff is $p_{s}$ and the junior creditor's payoff is $p_{r}$. Then, $p_{1}=\max \left(y_{0}-p_{0} .0\right)$ The sentor creditor is paid first, so the junior creditor receives what is left over or zero. Therefore, the junor creditor wants the firm to choose whichever system maximizes the monetary return $y_{;}$; only this critenon for system choice will maximize the junior creditor's expected bankruptcy payoff. This analysis holds. though, only if the junior creditor focuses on the mean bankruptcy retum. It can be shown that the jumor creditor would prefer a system with a lower mean retum and a higher vanance if the junior ereditor would expect to receive nothing even under high realizations of the high mean procedure. It is unclear how common this preference would be in practice. 
either system ( $L$ or $R$ ). A senior claimant would be indifferent to the firm's bankruptcy choice if it would be paid in full under both procedures. Such a creditor would be unwilling to incur the cost of a bankruptcy bribe to induce the firm to choose optimally. A senior creditor who expected to be paid in full regardless of the bankruptcy system the insolvent firm chose, however, would hold riskless debt, and this is unusual. On the analysis so far, then, if systems $L$ and $R$ both respect absolute priority, creditor conflict would seldom exist: Every creditor would be willing to bribe the firm to choose the optimal system except senior creditors who held riskless debt.

Trade creditors, however, would sometimes share the firm's preference for system $R$, even when $R$ is inefficient, because the firm can operate for a longer time under a reorganization system. ${ }^{71}$ A trade creditor may prefer $R$ if the firm would be liquidated piecemeal under system $L$ and the firm would be hard for the creditor to replace. The creditor, perhaps, could earn more in new transactions with the firm during the pendency of a wasteful reorganization attempt than it would lose by having its prebankruptcy debt collected under an inefficient system. Trade creditors who anticipated preferring system $R$ in all cases would be unwilling to bribe the firm to choose system $L$ when $L$ turned out to be optimal for creditors as a group. Too many such holdouts could preclude bankruptcy contracting.

The current Bankruptcy Code binds minority dissenters in a reorganization proceeding to the deal a majority prefer in order to avoid inefficient holdout behavior. ${ }^{72}$ For similar reasons, a trade creditor who prefers an inefficient bankruptcy contract should also be bound to the bankruptcy bargain that the ex ante majority prefer. The freedom to contract should not be used to prevent efficient contracting. ${ }^{73}$

In sum, if the ban on contracting for bankruptcy systems were repealed and majority rule were to govern the contracting process, the current U.S. system would make a better contribution to the maximization of social wealth. The National Bankruptcy Review Commission's recommendation that the current ban on bankruptcy waivers should be continued is, therefore, disappointing. ${ }^{74}$ The Commission gave three unsatisfactory reasons for this recommendation. First, it noted that creditor collection remedies are sometimes restricted, so bankruptcy restrictions are consistent with a commitment to freedom of contract generally. ${ }^{75}$ This argument holds only if the remedy

71. Trade creditors are either suppliers or customers of the insolvent firm.

72. See 11 U.S.C. \$ 1126 (c).

73. Letting the contract preferred by a creditor majority control also would reduce transaction costs. Creditors with claims sufficiently small as not to make bankruptcy contracting worthwhile would use the majoritarian system: For the reasons given above, this is the system they also would commonly prefer.

74. See supra text accompanying note 18 .

75. See 1 NATIONAL BANKRUPTCY REVIEW COMmission, supra note 4, at 478-79. 
restrictions are themselves justified, an assumption that is questionable ${ }^{76}$ and not defended in the Commission's report. There are also obvious differences between contracting for particular remedies and contracting for entire systems, but the Commission did not pursue these differences. Second, the Commission was concerned that the firm could contract with one or a few creditors to the detriment of the rest. ${ }^{77}$ For example, the firm could agree to let a powerful bank collect its debt in full. This is a legitimate concern, but it is not relevant to the question of whether a firm should be permitted to contract with its creditors to induce the use of a normatively defensible bankrupicy system. As Part III shows, such a system would prohibit contracts such as the supposed one between the firm and a powerful bank. Finally, the Commission believed that parties would not write bankruptcy contracts because "it is highly improbable that parties can accurately predict adequate relief given the myriad unforeseeable consequences that might accompany the debtor's financial collapse at an unknown point in the future. Bankruptcy is designed to provide a structure to deal with unforeseeable events ...."78 This view is irrelevant. No one disputes that the state should supply parties with a default bankruptcy procedure if they do not contract for one. Parties who feel themselves unable to foresee future events well enough to write bankruptcy contracts could use the default procedure while the others would not. The Commission's view here is also inconsistent with its recognition of the widespread current attempts to substitute private remedies for those the Code provides. ${ }^{79}$ Given the weak case the Commission makes, Congress should reject its recommendation to prohibit all bankruptcy waivers.

\section{MANDATORY BANKRUPTCy RULES}

Part I argued that a bankruptcy system is a necessary part of a business law that maximizes social wealth. Part II then showed that while $a$ bankruptcy system is needed, the question of which system parties should use in particular cases should be for the parties to decide. This part will argue that these systems should contain mandatory structural rules that protect the integrity of a bankruptcy system but should not contain mandatory rules whose goal is to augment the bankrupt estate. This argument is illustrated by an analysis of four mandatory rules in the current Bankruptcy Code: the rule automatically staying debt collection while a bankruptcy proceeding is in process; the rule that establishes the disagreement payoff for secured creditors who dissent to a

76. See, e.g., Alan Schwartz, The Enforceability of Security Interests in Consumer Goods, 26 J.L. \& ECON. 117 (1983) (arguing that the regulation of security interests is inappropriale on economic grounds).

77. See 1 NATIONAL BANKRUPTCY REVIEW COMMisSION, supro note 4, at 480-82.

78. Id. at 486.

79. See supra text accompanying notes 16-17. 
reorganization plan; and the two rules preventing a solvent party from refusing to deal further with a bankrupt contracting partner or that partner's assignee. ${ }^{80}$

\section{A. Mandatory Rules in General}

A mandatory bankruptcy rule is justifiable if the rule (1) is necessary to protect the integrity of the system itself, or (2) enhances ex post efficiency when the parties cannot reach the efficient outcome on their own. The second justification is subject to the constraint that the mandatory rule not create inefficient incentives for parties at earlier stages of their economic relationship. A rule that fails these justifications cannot create new tangible wealth for creditors and so will not make the bankrupt firm or its creditors better off on net. The losers from the rule will protect themselves in the ex ante prices or interest rates they charge, so the firm and the winners do not gain, all things considered.

Turning to illustrations of these claims, $\S 362$ of the current Code automatically stays creditor collection efforts when the insolvent firm files a bankruptcy petition. ${ }^{81} \mathrm{~A}$ stay commonly continues in force until the bankruptcy proceeding ends, and the firm cannot waive its right to stay collection in the lending agreement. ${ }^{82}$ In many cases, some form of stay is essential to the existence of an efficient bankruptcy system. As remarked above, creditors have an incentive to collect debts promptly in state courts rather than coordinate collection efforts with other creditors. The process of individual collection under local law must be halted for a bankruptcy system to function. To illustrate, assume that no single creditor has a mortgage or security interest in all of the insolvent firm's assets. A secured creditor with a right to a subset of the assets attempts to foreclose. If the collateral is worth

80. Barry Adler argues that the preference rules should be defaults rather than immutable but also believes that most parties would opt for the current system. See Barty E. Adler, A Re-Examination of NearBankruptcy Incentives, 62 U. CHI. L. REV. 575, 606 (1995).

81. See 11 U.S.C. $\$ 362$ (a) (1994). A general analysis of the automatic stay can be found in F.H. Buckley, The American Stay, 3 S. CAL. INTERDISC. L.J. 733 (1994). A claim that insolvent firms sometimes use the stay power strategically to extort rents from creditors is made by Daniel Keating, Offensive Uses of the Bankruptcy Stay, 45 VAND. L. REv. 71 (1992).

82. There is a conflict in the case law regarding whether a firm can waive the automatic stay for the benefit of a secured creditor after insolvency has occurred. Compare In re Club Tower L.P., 138 B.R. 307 (Bankr. N.D. Ga. 1991) (enforcing a stay waiver), with In re Sky Group Int'l, Inc., 108 B.R. 86 (Bankr. W.D. Pa. 1989) (refusing to enforce a stay waiver). If such a stay waiver is enforced and the secured creditor has a contract right to take important assets, there may be too little of the firm left to reorganize, which inclines courts not to enforce the stay waiver. On the other hand, if the secured creditor has the ultimate right to take the key assets, the other creditors may have no realistic interest in the bankruptcy proceeding, which inclines courts to enforce the waiver. Stay waivers are analyzed in Daniel B. Bogart, Games Lawyers Play: Waivers of the Automatic Stay in Bankruptcy and the Single Asset Loan Workout. 43 UCLA L. REV. 1117 (1996); and Marshall E. Tracht, Contractual Bankruptcy Waivers: Reconciling Theory, Practice, and Law, 82 CORNELL L. REV. 301 (1997). A theoretical argument in favor of enforcing stay waivers when the firm has one dominant creditor is made by Douglas G. Baird \& Randal C. Picker, A Simple Noncooperative Bargaining Model of Corporate Reorganizations, 20 J. LEGAL STUD. 311, 328-49 (1991). 
more to the firm than to the market, preventing foreclosure would maximize the ex post value of the estate. Hence, to let secured creditors (or creditors with judgment liens) foreclose before a decisionmaker resolves the value issue would vitiate the goal of the bankruptcy system. Because this argument applies to any conceivable bankruptcy system, every system needs a mandatory automatic stay rule for the common case. ${ }^{83}$

Turning to nonstructural rules, the current Code provides that if a creditor objects to a plan of reorganization that a majority of creditors in its class prefer, the plan needs to award the objecting creditor only the market value (i.e., the liquidation value) of its claim. ${ }^{84}$ If the reorganization plan is well conceived, the property underlying the claim will be worth more to the firm than to the market. The Bankruptcy Code could award the creditor the property's going-concern value to the firm less a penny, the property's lower value to the market, or a sum in between. Giving the dissenting creditor market value awards all of the difference between the property's going-concern and liquidation values to the insolvent estate.

The last illustrative set of rules permits the debtor in possession ${ }^{85}$ or the debtor's bankruptcy trustee to require a solvent party to continue to perform a contract with the insolvent firm or that firm's assignee. To illustrate the former aspect of this rule's operation, suppose the insolvent firm is the buyer in a three-year supply contract. It becomes insolvent in the second year. The seller may have an incentive to cancel the remainder of the contract because dealing with a bankrupt buyer commonly is riskier and more time consuming than dealing with a solvent buyer. Before adoption of the 1978 Bankruptcy Code, the seller probably had a state law right to cancel. Section 2-609 of the U.C.C. gave a seller with a "reasonable" belief that its buyer cannot perform under the contract the right to demand "adequate assurances" of performance,

83. A recent theoretical analysis argues that if free contractung about insolvency were permitted in the absence of a state-supplied bankruptcy system, creditors sometımes could not solve their coordination problem by writing contracts with the firm. When creditors differ in the amounts they lend and they also arrive sequentially, the incentive to be free to rush to collect would induce some ereditors (for some values of the economic parameters) not to sign bankruptcy contracts. A bankruptcy system is needed. the paper claims, to prevent rushes to collect. See Stanley D. Longhofer \& Siephen R. Peters. Protectuon for Whom? Creditor Conflicts in Bankruptcy (Mar. 1997) (unpublished manusenpt, on file with the Yale Law Joumul). When the insolvent firm must choose a bankruptcy system and all systems in the chosce set appropnately restrict creditors' collection rights, Pan II showed that partes probably would wric bankruptey contracts. Therefore, the automatic stay appears to be a structural rule that partly constitutes an optumal bankruptcy system. Consequently, paries should be prohibited from waving the stay in the lending agreement. Nevertheless, the United Kingdom and Spain, among others. do not stay secured creditors from foreclosing as soon as insolvency occurs. For critical analyses of these systems. see Esteban van Hemmen Almanzor. The Spanish Law of Suspension of Payments: An Economic Analysıs from Empincal Evidence (Sept. 5. 1997) (unpublished manuscript, on file with the Yale Law Journal); and John H. Armour. Corporate Reorganization in the UK and US: Comparative Efficiency (Sept. 5. 1997) (unpublished manuscnpt, on file with the Yale Law Journal).

84. See 11 U.S.C. $\S 1129(a)(7)(A)(i i)$.

85. The Bankruptcy Code permits the insolvent firm to operate under the control of its managers during the course of a reorganization. The firm is then referred to as the "debior in possession." II U.S.C. $\S \S 1107,1108$. 
and to cancel if adequate assurances were not forthcoming. ${ }^{86}$ Bankrupt firms sometimes are poor bets to perform and often could not give credible assurances. Many parties, however, protected themselves by express contract, probably to avoid litigation over whether the solvent party's belief that its contract partner could not perform as agreed was "reasonable" or whether the insolvent party's assurance that it nevertheless would perform was "adequate." A common commercial term, called an "ipso facto clause," gave either party the right to cancel the contract if the other party instituted an insolvency proceeding. ${ }^{87}$

Section 365 of the current Code gives the trustee or the debtor in possession the right to assume or reject the unperformed parts of contracts to which the firm is a party. ${ }^{88}$ The trustee may also assign contracts that she assumes. ${ }^{89}$ Section 365 also declares ipso facto clauses unenforceable, thereby eliminating the parties' ability to contract for an explicit right to exit, and declares unenforceable contract terms that prohibit assignment. ${ }^{90}$ Do the three nonstructural rules enhance ex post efficiency without worsening the parties' ex ante incentive to invest in increasing the value of the contract?

\section{B. Mandatory Rules and Ex Post Bargaining}

A preliminary analysis suggests that mandatory rules are unnecessary to achieve ex post efficiency. To see why, consider the sales contract example above and assume (1) the seller's expected cost of continued performance would exceed the seller's expected gain, (2) performance would generate monetary gains for the estate that would exceed the seller's net loss, and (3) state law or private contract would permit the seller to exit. The first and third assumptions imply that the seller would announce its intention to cancel the contract, but the second assumption implies that the buyer or its bankruptcy trustee would bribe the seller to continue. The trustee's compensation is an increasing function of the amount the trustee brings into the estate. ${ }^{91}$ Thus, if the seller would lose $\$ 100$ from continued performance while the estate would gain $\$ 200$, the trustee has an incentive to pay the seller some sum between $\$ 100$ and $\$ 200$ to continue.

The seller would also continue if bankruptcy law eliminated its right to exit. To see why this statement is not trivial, assume now that the seller would

86. U.C.C. \& 2-609 (1989).

87. Ipso facto clauses were in widespread use before the 1978 Bankruptcy Code banned them. See Bankruptcy Reform Act of 1978, Pub. L. No. 95-598, § 365(e), 92 Stat. 2549, 2576 (codified at 11 U.S.C. $\S 365(\mathrm{e})) ;$ S. REP. No. 95-989, at 59 (1978), reprinted in 1978 U.S.C.C.A.N. 5787, 5845 (explaining that the clauses were banned because they "frequently hamper[ed] rehabilitation efforts").

88. See 11 U.S.C. \$ $365(a)$.

89. See id. $\$ 365(\mathrm{f})$.

90. See id. $\S 365(\mathrm{e})(1)$, (f)(1).

91. See id. $\$ \S 326,330$. 
lose $\$ 200$ from continued performance while the estate would gain only $\$ 100$. Then the seller would exit even under $\S 365$ : There is some sum between $\$ 100$ and $\$ 200$ that the seller could pay to the buyer or its trustee for permission to exit. ${ }^{92}$

These examples should not be surprising. When state law controls the seller's right to exit, the seller has a "property right" to cancel the contract upon insolvency; when $\S 365$ controls, the insolvent buyer has a property right to require performance. Coasean conditions of low transaction and information costs seem to be met here, as the bargaining is between two parties who commonly are well informed. Therefore, the initial location of the propenty right is irrelevant to efficiency, and sellers will perform contracts with bankrupt firms when the monetary return from performance would exceed the seller's costs, and cancel contracts when this condition fails, under either the Bankruptcy Code or prior state law. Similarly, when it is efficient for property to remain in the estate, then it will remain there whether the law regulates a dissenting creditor's payoff or not.

The estate does benefit ex post from $\S 365$, but these benefits come with a price. When the estate holds the property right over contract performance, the seller must bribe it in order to exit. As a consequence, the seller will raise the product price to the firm. When the seller has the property right, creditors will charge the firm a higher interest rate than they would charge if the insolvent estate had the property right (because when the seller has the property right, the estate will be smaller). Thus, any increase in the ex post value of the estate is offset by the shrinkage in the estate caused by worsened terms of trade that the disadvantaged parties exact. This argument can be generalized to any rule that creates no new social wealth but only shifts ex post surplus from one set of bankruptcy claimants to another.

To summarize, the mandatory automatic stay rule is necessary to a bankruptcy system because the rule preserves the ability of the system to decide whether to continue firms in existence or liquidate them. Given that a stay is in place, however, mandatory bankruptcy rules are questionable on two grounds. First, an informal analysis suggests that because the parties can renegotiate after insolvency, the insolvent firm will perform contracts that generate net monetary gains, whether a mandatory rule is present or not, rendering mandatory rules unnecessary for achieving ex post efficiency. ${ }^{93}$

92. When parties renegotiate before an insolvency proceeding is instituted, but with the awareness of how these proceedings go, the seller could pay the buyer directly for permission to cancel the contract. When parties renegotiate during bankruptcy and the buyer is a deblor in possession. the seller also could pay the buyer directly. And when there is a trustee, he or she could accept payments for the estate's benefit. Thus, the analysis assumes that under current law the solvent panty could pay money to the insolvent party in a renegotiation over whether performance should contunue.

93. If the buyer or trustee cannot renegotiate with the seller, two inefficiencses can anse in the $\$ 365$ case: (1) Excessive acceptance occurs when the buyer may accept an inefficient contract (the buyer's gain from performance is less than the seller's loss); or (2) excessive rejoctuon oocurs when the buyer may reject an efficient contract (the buyer will not take fully into account the gain the seller would make from 
Second, the division of surplus in an ex post renegotiation will differ if the parties are renegotiating against the background of a mandatory rule instead of a default. Because parties will anticipate the results of the renegotiation game, whether a rule is mandatory or not can affect the parties' earlier economic decisions. The desirability of a mandatory rule, therefore, cannot be fully assessed without an analysis of these earlier decisions. Current bankruptcy theory omits this analysis. The next two sections sketch how a more complete analysis of mandatory bankruptcy rules should proceed.

\section{Section 365 and Ipso Facto Clauses}

Renegotiation in the $\S 365$ context differs from pure Coasean bargaining because one of the Coase Theorem assumptions does not hold here. ${ }^{94}$ The theorem assumes perfect capital markets, which implies that parties can finance all efficient trades; yet a bankrupt firm is cash-constrained. ${ }^{95}$ It is also common when analyzing contract issues to assume that a court can calculate expectation damages accurately. The buyer's damages (against a seller who cancels) are the difference between the buyer's valuation for performance and the price. ${ }^{96}$ Given the difficulty of reconstructing valuations in lawsuits, courts could err in finding these damages. When courts can err, there are two competing efficiency effects. If the seller is free to exit after insolvency, the seller sometimes will cancel when trade would be efficient. On the other hand, if the seller is free to exit, the buyer cannot behave strategically in bankruptcy, and this will improve the buyer's incentive to invest. The parties' contractual freedom to permit the seller to exit thus seemingly should be restricted (in a world of imperfect property rights) if the inefficiency effect of too little ex post trade dominates the inefficiency effect of worsening the buyer's incentive to invest.

performance because the buyer, being insolvent, cannot be made to pay the seller compensatory damages after rejection; thus, the buyer may reject a contract that is a loser for it although the seller's gain would exceed the buyer's loss). Jesse Fried assumes that renegotiation is seldom possible and suggests amendments to the Bankruptcy Code that respond to the excessive rejection danger. See Jesse M. Fried, Executory Contracts and Performance Decisions, 46 DUKE L.J. 517, $539-66$ (1996). Fried's "no renegotiation" assumption seems inadequately motivated, however. For example, he argues that the trustec sometimes would have to renegotiate a number of related contracts in order to benefit the estate, and says: "If any one of these ... parties refuses to renegotiate the price with the trustee of Firm's estate, the trustee may be required to reject all of the contracts." Id. at 534. Why a party would refuse to renegotiate is not explained. In addition, renegotiation after insolvency is common, as is evidenced by frequent bankruptcy workouts and debt restructurings. See, e.g., Schwartz, supra note 3, at 595 n.l.

94. This section draws from Yeon-Koo Che \& Alan Schwartz, Section 365 and Mandatory Bankrupicy Rules (1998) (unpublished manuscript, on file with the Yale Law Journal), which contains an extensive discussion of the question whether ipso facto clauses should be enforceable and a formal showing of the economic logic that underlies the claims briefly summarized here.

95. A concise list of the assumptions that generate the Coase Theorem is in Elizabeth Hoffman \& Matthew Spitzer, The Coase Theorem: Some Experimental Tests, 25 J.L. \& ECON. 73, 73 (1982).

96. If the seller has the property right, there is no lawsuit: The seller simply exits. If the estate has the property right and assumes the contract, the seller would be liable if it refused to perform. 
A simple model illustrates why this tradeoff exists. Let a firm borrow the cost of a project from creditors, as in the model in Part II, and later make a contract with a seller for an input to production. The firm derives both monetary and private benefits from pursuing the project (denoted $y$ and $b$, respectively). The contract price is $p$. If the firm becomes insolvent and the seller cancels the contract, the project cannot be performed. Upon insolvency, the firm, denoted the "buyer," becomes either a debtor in possession or a bankruptcy trustee, but the firm's manager-owners continue to operate it. The creditors are assumed to have priority over the seller, and the project's return in the insolvency state is assumed to be less than the project's cost. Thus, if the buyer does reject, the seller's claim for damages will be worthless; creditors lent the project's cost and are assumed to have priority, so there will be nothing left for the seller to take. On the other hand, if the seller cancels, it is initially assumed that ipso facto clauses are illegal so the buyer can sue the seller for damages. To capture the idea that solvent parties prefer not to deal with insolvent parties, the cost to the seller of performing the contract, $c$, is assumed to be zero if the buyer is solvent and greater than zero if the buyer is insolvent.

To begin, assume that courts can measure the insolvent buyer's expectation damages accurately and consider the case when returns if the project is successful would exceed the contract price $(y>p)$. The buyer then could pay for the seller's performance. The seller would prefer to breach if her loss from performance would exceed the buyer's damages. The loss would be the difference between the seller's cost and the price $(c-p)$. The buyer's true expectation damages are $y-p$. Hence, the seller will perform if $y-p>c-p$, or if $y>c$, and breach otherwise. The seller performs, that is, only when the buyer's project would generate a net monetary return.

Next (retaining the assumption that ipso facto clauses are illegal), consider the same case but permit courts to err in computing damages. On this assumption, because damages are awarded only when they are positive, the damages the seller expects to pay on breach will exceed the true damages." As a consequence, the seller sometimes would prefer performance although her cost would exceed the project's monetary return. If the buyer accepts performance, the project is pursued, and the buyer would pay the price to the seller, who then would lose $c-p$. The buyer would capture the private benefit $b$, and creditors would be paid the difference between the project's return and

97. Judicial error can be conceptualized by permitung the court to observe a random, unbiased estimate of the actual $y-p$. That is, the coun observes $y-p+z$ where $z$ is a random error term with positive variance and zero mean. This representation of damages implies that the expected damages the seller faces exceed true damages. If $z$ is positive, the cour overestimates the buycr's damages and the seller pays the erroneously high sum. If $z$ is negative, the coun underestimates the buyer's damages. These damages, however, are bounded from below by zero. Thus, a breaching seller expects to bear the full cost of judicial error on the high side, but expects not to profit fully from judicial errors on the low side. This biases the expectation damages upwards. 
the price $(y-p)$. The buyer in a renegotiation could obtain the outside parties' consent to nonperformance by paying them their status quo-i.e., their performance-payoffs. The seller would agree to exit if it could pay the buyer no more than the loss the seller would have incurred from performance, which is $c-p$, and the creditors would agree to permit cancellation of the contract if they were paid what performance would have brought, which is $y-p$. If the buyer renegotiates to reject performance, therefore, it can keep the difference between what the seller pays it to exit and what it must pay the creditors. This sum is $(c-p)$ (the seller's payment) $-(y-p)$ (the creditors' payment), or $c$ $-y$. The buyer thus will permit performance only when the private benefit it obtains would exceed the monetary payment it would receive from cancellation. That is, the buyer allows the seller to perform the contract when $b>c-y$, or when $b+y>c$. This is the condition for efficient trade, for when it holds, the total benefits from performance exceed the cost.

Banning ipso facto clauses in a world of judicial error appears to increase ex post efficiency. These clauses define a solvent party's exit on insolvency not to be a breach. In the example above, the seller could cancel the contract without paying damages. In this event, the buyer could induce performance only by compensating the seller's loss, and the buyer could do this only if the monetary return from performance would exceed the seller's cost. This efficiency gain from increasing the number of cases when the parties trade ex post-i.e., from banning ipso facto clauses-is nonmonetary. Under the ban, the contract is performed when $b+y>c$. This implies that there is performance when $y>c$. Under current law, all contracts that generate net monetary gains are performed, just as all of these contracts were performed when ipso facto clauses were legal. The ex post efficiency gain from the ban is exclusively a consequence of the ability of the buyer's owner-managers to consume private benefits that would otherwise be lost. Therefore, the conclusion of the informal analysis is confirmed. The parties will perform contracts that generate net monetary gains whether $\S 365$ is mandatory or not.

Turning to the parties' earlier economic decisions, permitting the seller to exit freely will create more efficient investment incentives. To see why, recall that in the example above the buyer uses the threat of high damages either to compel the seller to perform at a loss or to buy the right to exit. As to the effect on investment, when solvent parties anticipate increased losses in bankruptcy, they will increase the sum the buyer is required to pay if solvent. To be precise, in order for the buyer to borrow a sum equal to the expected value of its project, or to obtain credit from a seller at the expected cost of extending credit, the buyer must promise these parties a return (if the buyer is solvent) that exceeds project or credit cost. When the buyer must share the project's upside return with creditors, the buyer will not exert effort until the marginal cost of effort equals the marginal gain. In addition, the combination of a mandatory rule and the possibility of judicial error permits the buyer to 
earn private benefits in more cases. Therefore, the buyer's expected harm from bankruptcy is lower, and the buyer will exert less effort to avoid bankruptcy.

An ipso facto clause ameliorates the underinvestment effect because it eliminates the buyer's ability to behave strategically. The buyer no longer could threaten to sue for excessive damages in order to force performance or capture renegotiation rents because the clause permits the seller to exit without paying damages. As a consequence, the buyer must promise the outside parties a lower return in the solvency state to obtain credit. The buyer can keep more of the upside and has better investment incentives.

Ipso facto clauses appear to have competing efficiency effects: The clauses dampen ex post trade but ameliorate underinvestment. Bankruptcy law nevertheless should not ban these clauses. If the firm's private benefits are excluded from the efficiency calculus, then the ban is unambiguously inefficient. The ban worsens investment incentives without generating an offsetting efficiency gain. A firm's private benefits should not count in a normative bankruptcy analysis. A bankruptcy system whose function is to maximize the monetary value of the insolvent estate should not enact wealthreducing bans on private contract in order to increase the nonmonetary utility of an insolvent firm's owners or managers. Were an ipso facto clause ban to be efficient, all things considered, U.C.C. § 2-609 (which makes a version of the clause the default term) could be converted into a ban against the ipso facto clauses. ${ }^{98}$

\section{Anti-Assignment Clauses}

Sections 365(c) and 365(f) of the Bankruptcy Code permit the trustee to assume a contract and then assign the contract to a third party to perform, despite a clause in the contract prohibiting assignment, except in unusual cases. ${ }^{99}$ The paradigmatic example of an unusual case in which a court will uphold an anti-assignment clause is a contract under which the insolvent firm was to render personal services to the solvent party. ${ }^{100}$ Otherwise, the trustee or debtor in possession may assign a contract it cannot or prefers not to perform. The Code's refusal to enforce anti-assignment clauses works in a similar fashion as the ban on ipso facto clauses. If courts can calculate

98. See U.C.C. \$ 2-609 (1989). The analysis supra Part II did consider private benefits because its object was to predict what contracts parties would wnte about banknuptcy were they free to contract. The normative claim for free contracting over bankrupicy systems, however. rested on the ability of contract to increase the monetary return the firm could promise to creditors when the firm was insolvent, and thus to permit more efficient projects to be funded. Increasing the creditors' insolvency return in order to facilitate economic activity is a bankruptcy function.

99. See 11 U.S.C. § 365(c), (f) (1994).

100. Two recent cases discuss the provisions of the current Code regulating assignment. See Institut Pasteur v. Cambridge Biotech Corp., 104 F.3d 489, $492-93$ (Ist Cir.), cert. denied, 117 S. Cl. 2511 (1997): Summit Inv. \& Dev. Corp. v. Leroux, 69 F.3d 608, 612-14 (1st Cir. 1995). 
expectation interest damages accurately, the trustee will only assign contracts that are efficient for third parties to perform, whether an anti-assignment clause is enforceable or not. Outlawing these clauses will shift ex post surplus to the estate, but the insolvent firm or its creditors will not be better off on net because the effect of the ban will be priced out ex ante. Also, the ban probably worsens investment incentives for the reasons already stated. ${ }^{101}$

To establish these conclusions, assume that an insolvent firm-the buyer in the model above-will be liquidated. There is a set of solvent buyers that could profitably perform the contract. If it would cost the solvent seller nothing to perform for any solvent party, the contract will be efficient to assign, and the seller will not object to assignment. ${ }^{102}$ If the seller anticipates wanting to perform for any solvent party, however, the contract would not contain an anti-assignment clause. To make the problem interesting, assume that the seller's performance cost is partly a function of the identity of the party with whom it deals. Therefore, it may be profitable for the seller to perform at the original contract price with some third-party assignees, but not others. An enforceable anti-assignment clause would permit the seller to refuse performance when it would lose money.

To make the analysis more precise, let $c_{b}$ denote the seller's cost if it dealt with the contract buyer, and let $c_{t}$ denote the seller's cost if it must deal with the third party that the buyer or its trustee chooses. The seller would oppose assignment if $c_{t}>p \geq c_{b}$, i.e., if the performance for the assignee would be at a loss. The assignee would earn $y_{t}$ from performance, and the contract would be efficient to perform if the seller's performance cost were less than the third party's return $\left(c_{t}<y_{t}\right)$.

To see that the anti-assignment clause ban will not enhance ex post efficiency assume first that the clause is illegal and that a court could find a third-party assignee's expectation damages accurately. The third party would accept assignment if its expected project return would exceed its cost. The cost is the price an assignee would pay to the seller for the product plus the price the assignee would pay to the trustee for the right to perform. The latter price is denoted $x$. The largest value that $x$ could take, denoted $x_{\max }$, would ensure that the assignees will earn no profit from the assignment. The assignee earns no profit if $y_{t}-p-x=0$, so $x_{\max }=y_{t}-p$. Let $d_{\max }$ denote the largest bribe that the seller would pay the trustee not to assign the contract. This would equal the seller's loss from performance for the assignee: $d_{\max }=c_{t}-p$.

The contract would be efficient to perform with the third-party assignee if the assignee's gain will exceed the seller's cost. Note that if $y_{t}>c_{b}$, then $y_{t}-p>c_{t}-p$. Therefore, $x_{\max }>d_{\max }$. The most that the third party would pay

101. See supra Section III.C.

102. When the seller's performance cost is zero, the third party's project return necessarily exceeds cost, so performance would be efficient. No one would bid for the contract unless their expected return would exceed the price, so the seller knows it will be paid. 
for the contract- $x_{\max }$-is greater than the most the seller would pay the trustee not to assign $-d_{\max }$. The contract would thus be assigned. On the other hand, if the contract would be inefficient to perform, then $x_{\max }<d_{\max }$. In this case, the most that a third party would bid for the contract is less than the most that the seller would pay the trustee not to assign. In sum, when the Bankruptcy Code bans anti-assignment clauses, the trustee can assign only those contracts that are efficient for third parties to perform.

The third party would also perform only efficient contracts if antiassignment clauses were legally enforceable, however. In this case, a third party would have to deal directly with the seller. When $y_{t}>c_{r}$ there is obviously a sum that an assignee could pay that would induce the seller to perform. Conversely, if the contract would be inefficient to perform, the third party could not pay the seller enough to perform it. As a result, contracts that are profitable for someone to perform ex post will be performed whether or not the Bankruptcy Code bans anti-assignment clauses.

The bankrupt estate does benefit ex post from the anti-assignment clause ban because the estate will either capture part of the surplus from efficient performance or realize a bribe for refusing to assign. This redistributional gain, however, will be priced ex ante, so there will be no net benefit. In addition, if the buyer's project must be financed by other creditors, then because the ban on the anti-assignment clauses lowers the solvent parties' insolvency return, the increased price these parties will charge for funds will prevent the buyer from realizing the full upside gain of the project. Reducing the buyer's solvency returns will likely induce a reduction in the buyer's incentive to invest. ${ }^{103}$

\section{CONCLUSION}

Bankruptcy analysis traditionally has focused on the problems that exist after insolvency has occurred. Scholars agree that a bankruptcy system should attempt to maximize the value of the insolvent estate for the benefit of creditors. High coalition costs prevent creditors from performing this task themselves by coordinating on jointly maximizing debt collection strategies. Scholars disagree on whether a bankruptcy system should pursue additional goals that may detract from value maximization, such as distributing value to employees or local communities. Most participants in bankruptcy debates do agree, however, that the problems that prevent creditors from coordinating strategies after insolvency would also be present ex ante, when the firm borrows money. Apparently because contracting about bankruptcy is thought to be impractical, few scholars have analyzed the mandatory nature of the U.S.

103. If courts can err in assessing expectation damages. the seller would sometumes have to perform for a third party when its performance cost would exceed the third party's retum. The efficiency gain. if any, would be the third party's private benefits, but these should not count in a bankruptcy analysis. 
bankruptcy systems. Parties are required to use the bankruptcy system the state supplies, and they cannot contract out of many of the rules in the monopoly system.

This Essay has argued that a bankruptcy system is a part of business law generally. The major goal of business law is to maximize social wealth. A bankruptcy system's pursuit of goals additional to wealth maximization apparently is either ineffectual or counterproductive. A bankruptcy system best realizes the goal of maximizing social wealth by maximizing the value of bankrupt estates. This maximizes creditors' payoffs when firms fail and thus permits creditors to reduce the cost of debt capital. As a consequence, firms finance more projects and have better incentives to invest in these projects. Requiring parties to use a single, state-supplied bankruptcy system does not maximize the value of bankrupt estates, because the optimality of a bankruptcy system is state-dependent: No system, however well constructed, is best for parties in all states of the world. Thus requring parties always to use the same system impairs the ability of firms to raise debt capital. In the world of bankruptcy, one size cannot fit all.

Many of the mandatory rules within bankruptcy systems are intended to augment the bankrupt estate. This is not an intelligible bankruptcy goal. Instead, a mandatory rule is justified only if it is necessary to preserve the integrity of the bankruptcy system itself or if the rule enhances ex post efficiency while not worsening the parties' incentives to invest in the contracts they make. The automatic stay rule in many cases appears necessary to the integrity of a bankruptcy system. Other mandatory rules, such as the rules regulating assumption and assignment of contracts, are harder to justify. These rules do not enhance ex post efficiency, do not create net gains for the estate, and worsen investment incentives.

This analysis has four normative implications. First, the state should permit parties to contract for the bankruptcy system that they prefer. Second, to prevent holdout problems, the state should bind a creditor minority to the contract that a majority of creditors prefer (just as it now binds a dissenting creditor minority to the reorganization plan a majority prefer). Third, a bankruptcy system should not contain mandatory rules that seek only to augment the value of bankrupt estates. Fourth, bankruptcy systems are sufficiently complex that creating them is probably beyond the resources of parties to typical credit extensions. That is, a bankruptcy system is largely a public good. The state thus should supply parties with a default system, but also with a set of additional systems among which parties can choose, just as states today supply parties with a set of default business forms, such as the close corporation, the public corporation, and the like.

Viewing bankruptcy through the lens of contract theory reveals bankruptcy's anachronistic character: Bankruptcy is a government enterprise. The state runs the postal system and the bankruptcy system, and restricts 
competition with both by law. This Essay's central claim is captured in a variation on a trendy slogan: Privatize bankruptcy. 
